\title{
Analysis of a Small, Vigorous Mesoscale Convective System in a Low-Shear Environment. Part I: Formation, Radar Echo Structure, and Lightning Behavior
}

\author{
KEVIN R. KNUPP AND BART GEERTS* \\ Earth System Science Laboratory, University of Alabama in Huntsville, Huntsville, Alabama \\ STEVEn J. Goodman \\ NASA/Marshall Space Flight Center, Huntsville, Alabama
}

(Manuscript received 3 September 1996, in final form 5 September 1997)

\begin{abstract}
The evolution of a small, vigorous mesoscale convective system (MCS) over northern Alabama is described using Doppler radar, GOES satellite, surface mesonet, lightning, and sounding data. The MCS formed near noon in a relatively unstable environment having weak synoptic forcing and weak shear. The initiation of separate lines and clusters of deep convection occurred in regions exhibiting cumulus cloud streets, horizontal variations in stratocumulus cloud cover, and variations in inferred soil moisture. MCS growth via merger of storms within clusters and lines, and among the clusters, was accomplished largely through intersection of storm-scale and mesoscale outflow boundaries. The MCS maximum anvil area $\left(\sim 60000 \mathrm{~km}^{2}\right.$ at $\left.220 \mathrm{~K}\right)$ and lifetime $(8 \mathrm{~h})$ were about 50\% that of the typical Great Plains mesoscale convective complex (MCC).

Despite its smaller size, this MCS displayed many aspects that typify the mostly nocturnal Great Plains MCS. The precipitation output was highly variable due to the transient nature of the intense convective elements, many of which produced microbursts. The radar measurements documented the formation of a stratiform region along the trailing side of an intense convective line. This stratiform region formed as decaying convective cores coalesced, rather than through advection of precipitation particles directly from the convective region. Combined GOES IR imagery and radar reflectivity analyses within the stratiform region show a sinking anvil cloud top in the presence of increases in the vertical radar reflectivity gradient within the cloud during the maturation of the stratiform region.

During its intense developing stages, the MCS generated a peak cloud-to-ground (CG) flash rate of $2400 \mathrm{~h}^{-1}$, comparable to rates produced by larger MCCs. Early on, positive CG flashes were most prevalent around intense convective core regions exhibiting strong divergence at anvil level. During the latter stages, the emergence of positive CG was coincident with the formation of a prominent radar bright band within the stratiform region. Thus, a bipole was established, but its length was quite short at approximately $50 \mathrm{~km}, 25 \%-50 \%$ of the distance documented in other MCSs.
\end{abstract}

\section{Introduction}

Mesoscale convective systems (MCSs), that is, systems of cloud and precipitation that include at least one thunderstorm cell during most of their lifetime (Zipser 1982), occur in a continuous spectrum from small, shortlived systems (e.g., Browning and Hill 1984; Knupp and Cotton 1987; Yuter and Houze 1995a) to long-lived mesoscale convective complexes (MCCs) exhibiting an

\footnotetext{
* Current affiliation: Embry-Riddle Aeronautical University, Prescott, Arizona.
}

Corresponding author address: Dr. Kevin R. Knupp, Earth System Science Laboratory, University of Alabama in Huntsville, Hunstville, AL 35899.

E-mail: kevin@atmos.uah.edu average maximum area ${ }^{1}$ of approximately $160 \times 10^{3}$ $\mathrm{km}^{2}$ and a lifetime of about $13 \mathrm{~h}$ (e.g., Maddox et al. 1982). Figure 1 presents area and lifetime values for 161 MCCs observed over the United States for the $1985-87$ period. While there is no clear minimum size or lifetime for an $\mathrm{MCS},{ }^{2}$ the smallest systems in the Southeast during the summer are short-lived, but most frequent (Geerts 1998, hereafter G98). MCCs are relatively rare, representing only a small fraction of the

${ }^{1}$ The MCS area has traditionally been defined as the area within the effective blackbody temperature $\left(T_{b}\right)$ isotherm of $-52^{\circ} \mathrm{C}$ as determined from GOES IR data (Maddox 1980). The value used in this paper is $220 \mathrm{~K}\left(-53^{\circ} \mathrm{C}\right)$

2 The definition of any threshold is of little value, since it would be instrument specific. MCCs are defined and typically described in terms of their cloud-top appearance (i.e., IR imagery from geostationary satellites), while smaller MCSs have been analyzed mainly by means of radar data. 


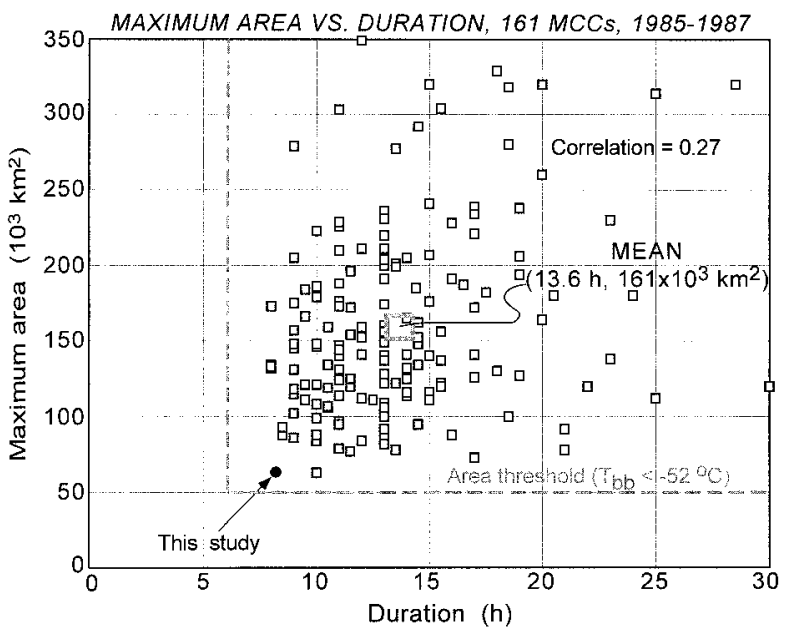

FIG. 1. Scatterplot of MCC duration vs maximum area for 161 MCCs classified during the $1985-87$ period. The area and duration means are shown. The point for the case study of this paper is shown by the solid dot. Data are taken from Augustine and Howard (1988, 1991).

total MCS population. For instance, MCCs are thought to represent less than $1 \%$ of all MCSs in the western tropical Pacific (Mapes and Houze 1993). The fraction is perhaps slightly larger over North America (E. Zipser 1996, personal communication).

In the United States (Maddox et al. 1982; Rodgers and Howard 1983; Rodgers et al. 1985; Augustine and Howard 1988, 1991; Cotton et al. 1989) and elsewhere (Velasco and Fritsch 1987; Miller and Fritsch 1992) MCCs typically develop in the late afternoon and attain maximum anvil size between midnight and sunrise. In contrast, the diurnal variation of small MCSs appears to be regionally variable. Over continental areas with significant baroclinic activity, the diurnal cycle of smaller MCSs is weak and ill defined. In a radar-based study of springtime MCSs in Oklahoma, Houze et al. (1990) report that the largest systems are longest lived and attain a peak size around midnight, whereas smaller systems $\left(13-38 \times 10^{3} \mathrm{~km}^{2}\right)$ have no clear diurnal preference. Smaller MCSs over tropical oceans may be more common at night (e.g., Churchill and Houze 1984), although the diurnal modulation is weak. In essentially barotropic environments, including the Southeast during much of the summer, smaller MCSs tend to develop around noon and weaken around sunset (G98), although the diurnal amplitude is about half that of the thunderstorm climatological patterns of Wallace (1975). Similar patterns also exist in west Africa (Martin and Schreiner 1981) and Australia (Wilson and Ryan 1986).

A number of previous studies have detailed the kinematic structure and evolution of some rather large MCSs in the central Great Plains (Johnson and Hamilton 1988; Houze et al. 1989; Brandes 1990; Biggerstaff and Houze 1991; Smull and Augustine 1993) and elsewhere (Chong et al. 1987; Hauser et al. 1988). The MCS structure at maturity has been the focus of these studies. Only a few studies have investigated the detailed aspects of MCS formation (e.g., Leary and Houze 1979; Keighton et al. 1991; Klimowski 1994; Yuter and Houze 1995a). In many cases, the MCS displays a characteristic organization consisting of a leading convective line and a trailing stratiform region. The stratiform region generally forms at a later stage, after the convective cells have become organized into a line.

Recent work has also examined the behavior of cloudto-ground lightning (CG) within mesoscale convective systems. Goodman and MacGorman (1986), examined the time-dependent behavior of CG within MCCs and found that MCCs produce an unusually large number of CG flashes over their lifetime (Table 1). A number of recent investigations have summarized the coevolving fields of equivalent reflectivity factor $Z_{e}$, airflow (in some cases), and CG in mesoscale convective systems (Rutledge and MacGorman 1988; Rutledge et al. 1990; Engholm et al. 1990; Keighton et al. 1991; Schuur et al. 1991; Hunter et al. 1992; Holle et al. 1994; Rutledge and Petersen 1994; Nielsen et al. 1994). These works have shown that many MCSs exhibit a bipolar CG pattern upon attaining a mature state consisting of a convective line (mainly negative $\mathrm{CG}$ ) with a trailing stratiform region (mainly positive CG). However, only several studies, summarized in Table 1 , have considered the $Z_{e}-\mathrm{CG}$-airflow relationship for the complete MCS life cycle.

This paper, along with Part II (Knupp et al. 1998), examines a small MCS. This MCS does not satisfy the Maddox (1980) MCC criteria, because it did not display an area of at least $50 \times 10^{3} \mathrm{~km}^{2}$ during six consecutive hours, although it did attain a maximum area of about $60 \times 10^{3} \mathrm{~km}^{2}$ near the end of its $7-8$-h total lifetime.

TABLE 1. Comparison of MCSs with well-documented cloud-to-ground lightning.

\begin{tabular}{|c|c|c|c|c|c|c|}
\hline Study & MCS description & $\begin{array}{c}\text { MCS } \\
\text { lifetime } \\
\text { (h) }\end{array}$ & $\underset{\left(10^{3} \mathrm{~km}^{2}\right)}{\operatorname{Max}}$ & $\begin{array}{c}\text { Max CG } \\
\text { rate } \\
\left(\mathrm{h}^{-1}\right)\end{array}$ & $\begin{array}{l}\text { Total CG } \\
\text { flashes }\end{array}$ & $\begin{array}{c}\text { Percent } \\
\text { positive } \\
\text { CG }\end{array}$ \\
\hline Goodman and MacGorman (1986) & Averages for $10 \mathrm{MCCs}$ around Oklahoma & $14 *$ & 160 & 2700 & 22300 & N/A \\
\hline Holle et al. (1994) & $\begin{array}{l}\text { 3-4 June } 1985 \text { over Oklahoma } \\
\text { (MCS II of their study) }\end{array}$ & 11 & $140 * *$ & 1300 & 7011 & 9.9 \\
\hline This study & MCS over Southeast & 8 & 60 & 2400 & 10335 & 4.0 \\
\hline
\end{tabular}

* These values are close to those of the average values for MCCs in the United States (Fig. 1).

$* *$ Area determined by $18-\mathrm{dBZ}$ contour at $0.5^{\circ}$ elevation. 
The MCS herein developed around noon on 13 July 1986 over the Southeast and weakened near sunset. This small MCS formed in the absence of a synoptic-scale frontal or baroclinic zone, which is often present for MCCs (e.g., Maddox 1983). This is the first detailed study of a small MCS that perhaps typifies MCSs that frequently form in the low-shear, nearly barotropic climatic regime that prevails over the Southeast during much of the warm season. Geerts (1998) has determined that about 50 MCSs form per month during June, July, and August over a major portion of the Southeast covering the respective latitude and longitude bounds of $31^{\circ}-38^{\circ} \mathrm{N}$ and $80^{\circ}-93^{\circ} \mathrm{W}$.

Because small MCSs have not been well documented in the literature, our approach in this paper is to describe the large-scale setting (section 3), the MCS development within this benign environment (section 4), and the evolution and structure of the MCS and its convective components (section 5). Our analysis primarily utilizes the Geostationary Operational Environmental Satellite (GOES) satellite, Doppler radar, and lightning measurements, the last of which is used to infer relative vigor of deep convection. A primary goal is to compare the attributes of this MCS (e.g., precipitation distribution, cloud-top structure, and CG lightning behavior) with those of the larger MCS/MCC. In Part II, a more thorough analysis of the origin of stratiform precipitation is presented, the evolution of mesoscale vertical velocity and vorticity is analyzed, and other mesoscale flow characteristics are described.

\section{Data sources}

This study utilizes special data that were collected on 13 July 1986 during the Cooperative Huntsville Meteorological Experiment (COHMEX). Components of the observational network (Fig. 2) consisted of 1) 89 automated surface stations deployed in a nested mesoscale network (a meso- $\beta$-scale outer network having approximately $50-\mathrm{km}$ spacing and an inner meso- $\gamma$-scale network having a station spacing of about $5 \mathrm{~km}$ ), 2) three Doppler radars (the S-band CP-2, and two C-band radars, CP-3 and CP-4) operated by the National Center for Atmospheric Research (NCAR), 3) a RADAP digital processor on the Nashville (BNA) WSR-57 National Weather Service radar, and 4) four lightning location and protection (LLP) direction finding systems operated by the National Aeronautics and Space Administration/ Marshall Space Flight Center. Although the COHMEX rawinsonde network was not operational on this day, serial soundings were acquired at 1200, 1800, 2000, and $2300 \mathrm{UTC}^{3}$ from sites RSA and MSFC shown in Fig. 2.

The analysis incorporates equivalent reflectivity factor $Z_{e}$ data from the BNA S-band WSR-57 radar, Dopp-

\footnotetext{
${ }^{3} \mathrm{UTC}$ is about $5.5 \mathrm{~h}$ ahead of local solar time.
}

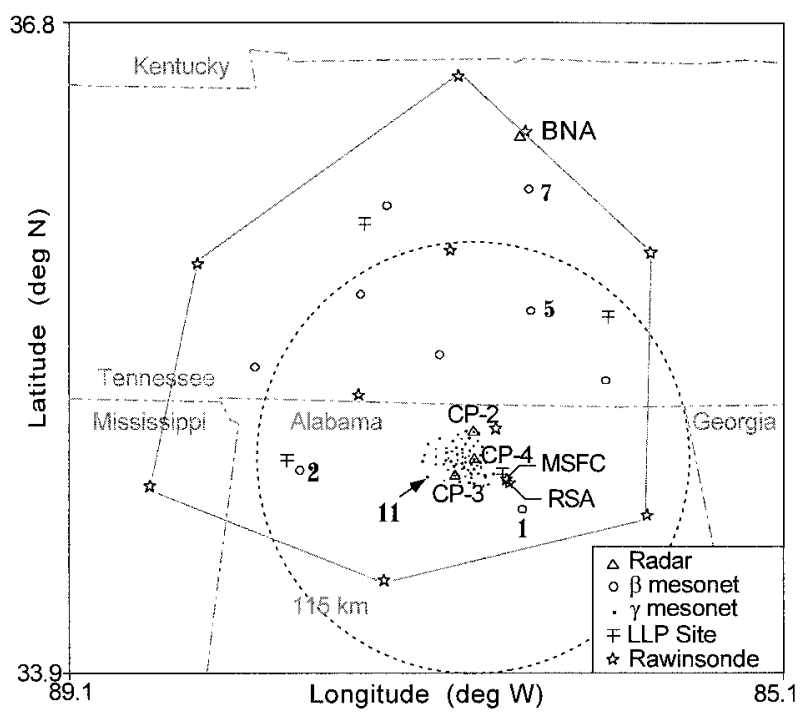

FIG. 2. Measurement platforms available for the Cooperative Huntsville Meteorological Experiment (COHMEX). The meso- $\gamma$ network is shown as a cluster of points in the vicinity of CP-4. The dashed circle represents the $\mathrm{CP}-4$ maximum unambiguous range of $115 \mathrm{~km}$. Numbers identify particular portable automated mesonet (PAM) sites.

ler velocity $V_{r}$, and $Z_{e}$ data from CP-4 (the only research radar that routinely conducted $360^{\circ}$ surveillance scans), CP-2 and CP-3 in single and dual modes surface mesonet data, and 30-min GOES satellite imagery. Since the MCS of interest produced extensive areas of heavy rain around the radars, the reflectivity factor obtained by CP-4 was significantly attenuated over limited regions. To alleviate this problem, a modified form of Hildebrand's (1978) attenuation correction scheme was implemented (Knupp and Chandrasekar 1993).

The $Z_{e}$ and $V_{r}$ data from CP-4 were interpolated to a 3D Cartesian grid for composite analysis using the CEDRIC software (Mohr and Miller 1983). In addition, range-height indicator (RHI) scans from CP-4 and CP2 were analyzed to ascertain system structure. Special effort was made to combine GOES IR, $Z_{e}$, and CG data quantitatively to examine the evolution of this MCS.

\section{The environment}

Large-scale patterns at 1200 UTC 13 July 1986 reveal a weakly baroclinic (benign) synoptic environment over the region, with the following key features also shown in Fig. 3.

- A surface stationary front was located $600 \mathrm{~km}$ to the north.

- Rather uniform temperatures of $25^{\circ}-26^{\circ} \mathrm{C}$, and dewpoints of $21^{\circ}-22^{\circ} \mathrm{C}$, existed over the region.

- An enhanced low-level pressure gradient over northern Alabama supported a $15 \mathrm{~m} \mathrm{~s}^{-1}$ low-level jet near $90 \mathrm{kPa}$ over the region (observed only over northern Alabama at Redstone Arsenal in Fig. 3b). 
- A short-wave trough was well to the north, near the surface stationary front (Fig. 3d).

- Synoptic-scale ascent was weak, as indicated by airflow parallel to the isobars on the $316-\mathrm{K}$ isentropic analysis in Fig. 3d, and by the lack of diagnosed quasigeostrophic vertical motion (not shown).

Two proximity soundings taken near the developing MCS are shown in Fig. 4. The first sounding (RSA) was released at 1730 UTC approximately $120 \mathrm{~km}$ ahead of the MCS (Fig. 5b), but the second (MSFC, 2004 UTC) sampled an environment perturbed by local deep convection (Fig. 5c). The 1730 UTC sounding displays a 1.7-km-deep boundary layer, abundant water vapor (precipitable water of about $50 \mathrm{~mm}$ ), and unstable conditions [convective available potential energy (CAPE) $\sim 2700 \mathrm{~J} \mathrm{~kg}^{-1}$ ]. Appreciable differences exist in all sounding parameters, apparently due to deep cumulus in the vicinity. The 2004 UTC sounding appears to be especially influenced by deep convection, as attested by the moist layer between 80 and $55 \mathrm{kPa}$, and winds that differ appreciably from earlier (1200 and 1730 UTC) soundings. The large difference between the two adjacent soundings suggests that convectively induced shear exceeds the ambient shear, such that the environment is ill defined (Brooks et al. 1994). We believe that the 1730 sounding better represents the undisturbed atmospheric profiles.

Although the winds at 1730 UTC were primarily zonal at all levels, the MCS moved south-southeastward at about $5 \mathrm{~m} \mathrm{~s}^{-1}$ (Fig. 4b). A comparison of the wind profile in our case to that of the "strongly classifiable", MCS defined by Houze et al. (1990) reveals a similar low-level shear vector $\left(7-8 \mathrm{~m} \mathrm{~s}^{-1}\right.$ magnitude, oriented $30^{\circ}-35^{\circ}$ to the right of line orientation), but much weaker upper-tropospheric flow in our case. The MCS motion is somewhat subjective and represents the movement of the main convective line within the MCS, not individual convective cells that moved from the west-northwest. The large departure between storm motion and deeplayer mean wind is not uncommon for MCSs in weakly forced environments (Stensrud and Fritsch 1994). In both soundings, the ambient wind shear was strongest in a direction parallel to the mature squall line, which was essentially zonal. In the direction of storm motion, the magnitude of the wind shear was much smaller, approximately $5 \mathrm{~m} \mathrm{~s}^{-1}$ between 1 and $4 \mathrm{~km}$.

\section{MCS initiation}

Between 1200 and 1800 UTC, the remnants of a nocturnal MCS traveled eastward over northern Tennessee (Figs. 5a,b). This decaying cloud field originated from an MCC over Missouri and was associated with apparent cyclonic rotation as seen in the cloud pattern in Fig. 5a. The MCS in this study formed just to the south of the decaying MCS in northern Tennessee around 1700 UTC. However, detailed GOES satellite imagery at 30-min intervals implies that the MCS of our study was not directly related to the MCC remnant, suggesting that the midtropospheric vorticity anomaly associated with this cloud field drifted eastward rather than southward.

GOES visible imagery during the initial development period (1600-1800 UTC, Figs. 5a,b) reveal significant variability in cloud cover and convective cloud organization, indicating an inhomogeneous atmospheric boundary layer (ABL). By 1500-1600 UTC lines of enhanced cumulus representing longitudinal rolls had developed largely within existing stratocumulus (Sc) cloud fields over northern Alabama, northern Mississippi, and southern Tennessee (Fig. 5a). The orientation of these rolls (west-southwest to east-northeast), slightly counterclockwise of the low-level jet at 1200 UTC (Fig. $4 \mathrm{~b}$ ), is consistent with inflection point instability ${ }^{4}$ in which cumulus clouds are organized in streets aligned about $20^{\circ}$ to the left of the geostrophic wind. By 1630 first echoes from a cluster of deep convection (labeled " $\mathrm{X}$ " in Fig. 5b) formed within the enhanced cumulus field east of CP-4, attained a state of maturity by 1800 UTC, and dissipated after 2000 UTC.

By 1800 UTC only limited Sc regions were located adjacent to enhanced $\mathrm{Cu}$ regions (Fig. 5b), which represent the initial deep convection of the MCS. These vigorous cumuli were arranged in short "transverse bands" oriented about normal to the west-southwest mean flow in the ABL. These features appear to be Rayleigh-Bernard rolls (Houze 1993, 61-64) that develop parallel to the shear vector (normal to the mean flow) under even stronger surface heating and lower gradient Richardson number (Brown 1980), calculated at approximately 0.2 from the 1730 UTC RSA sounding. Their wavelength is $8-10 \mathrm{~km}$, somewhat longer than a maximum of $7 \mathrm{~km}$ predicted by theory, assuming an ABL height of $1.7 \mathrm{~km}$ and an aspect ratio of 4 . The strong surface heating is consistent with the formation of these bands over a zone that had experienced appreciable insolation under low cloud cover largely void of the morning Sc. We believe that the enhanced transverse bands were forced by the thermal contrast between the cooler Sc region and the warmer, clearer region where these bands formed. Figure $5 \mathrm{~b}$ also shows the initial stages of another MCS component (C) approximately $120 \mathrm{~km}$ west of CP-4. This development suggests a superposition of transverse bands on the more extensive (but variable) cloud line whose endpoints are labeled E and W. MCS X formed on this same line.

The variability in shallow cumulus cloud (ABL) structure over the synoptically benign region was associated with preexisting, nonuniform Sc cloud fields. We hypothesize that horizontal variations in surface heat

\footnotetext{
${ }^{4}$ Infection point instability produces horizontal convective rolls in the presence of wind shear in the ABL. It is dependent on an inflection in the curvature of the wind profile. Houze (1993) provides a general description, and details are given in Brown (1980).
} 


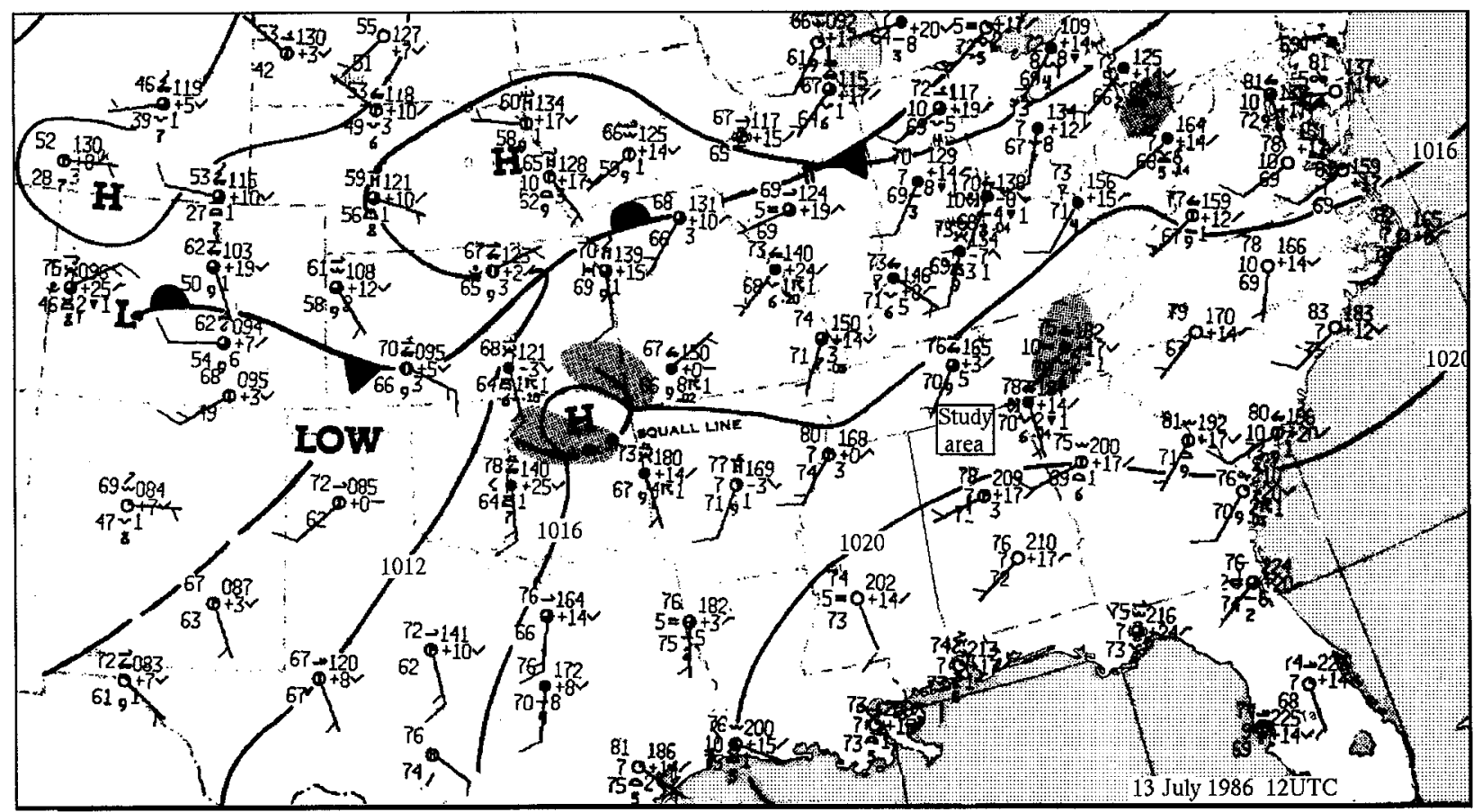

FIG. 3. Analysis at 1200 UTC 13 July 1986 about 5 h before the development of the MCS over the "study area" near the AlabamaTennessee border. (a) Surface analysis, with temperature and dewpoint temperature $\left({ }^{\circ} \mathrm{F}\right)$ and sea level pressure contoured every $4 \mathrm{hPa}$. (b) The 850-hPa analysis, with geopotential height (solid lines) contoured every $30 \mathrm{~m}$, temperature (dashed lines) contoured every $2 \mathrm{~K}$, winds at the radiosonde sites, and relative humidity shaded in gray scales as shown on the left of the figure. (c) The 200-hPa analysis, with the same conventions as (b) except that the gray shades indicate wind speed, in knots. (d) The 316-K isentropic analysis, with pressure (solid) contoured every $30 \mathrm{hPa}$, winds interpolated to a regular grid, and potential vorticity (shaded) in units of $10^{-7} \mathrm{~m}^{2} \mathrm{~s}^{-1} \mathrm{~K} \mathrm{~kg}^{-1}$. (e) Analysis of vertically integrated variables, precipitable water (solid), contoured every $5 \mathrm{~mm}$, lifted index (dashed) contoured every two units, and CAPE (shaded) with increments of $500 \mathrm{~J} \mathrm{~kg}^{-1}$.

fluxes were produced by the variable cloud shading, and perhaps modulated by secondary influences such as variations in soil moisture, topography, and vegetative type (forests to agricultural). In regard to the soil moisture influence, rainfall over the previous 7 days was negligible from central Georgia to central Tennessee (Fig. 6). In this case, the enhanced cumulus at 1800 UTC near points A-C, and the deep convection marked by $\mathrm{X}$ (Fig. $5 b$ ), are located near gradient regions of antecedent precipitation. Moreover, later development of deep convection on the flanks of the weakening MCS of this study, at points NE, NW, and S, display a similar behavior. Mesoscale circulations associated with horizontal variations in surface fluxes are believed to produce significant mesoscale circulations (e.g., Segal et al. 1995), and we hypothesize that such processes were important in the initiation of this MCS and later convective activity. While we cannot determine the relative roles of Sc cloud cover and soil moisture variations, we conjecture that both were important in producing variations in sensible heat flux and, hence, generating ABL convergence leading to initial deep convection, in this case.

\section{MCS output}

a. Rain

This MCS generated locally high but variable totals in both rainfall and CG lightning. Rainfall (24-h totals) plotted in Fig. 7 peaked near $50 \mathrm{~mm}$, and the large spatial variability over the meso- $\beta$ network is also found in the meso- $\gamma$ network. The large variability over spatial scales of less than $5 \mathrm{~km}$ over the meso- $\gamma$ network was produced by intense, transient deep convection exhibiting core diameters less than $5 \mathrm{~km}$ between 2000 and 2100 UTC. Rainfall measured at PAM 2 (Fig. 8c) demonstrates the dominance of convective precipitation. The total stratiform precipitation of $2-4 \mathrm{~mm}$ measured at sites PAM 1,2, and 11 over the southern $\beta$ mesonet represents $10 \%-20 \%$ of the total precipitation over this region. (The stratiform contribution at some heavy rainfall points was much lower at $0 \%-2 \%$.) This fraction is much less than the $30 \%-40 \%$ value estimated from larger MCSs (Johnson and Hamilton 1988; Tao and Simpson 1989), which we attribute to a limited duration of the mature (stratiform) stage. The paucity of stratiform rainfall may be related to the short-lived and relatively weak $\left(10-20 \mathrm{~cm} \mathrm{~s}^{-1}\right)$ mesoscale updraft diag- 

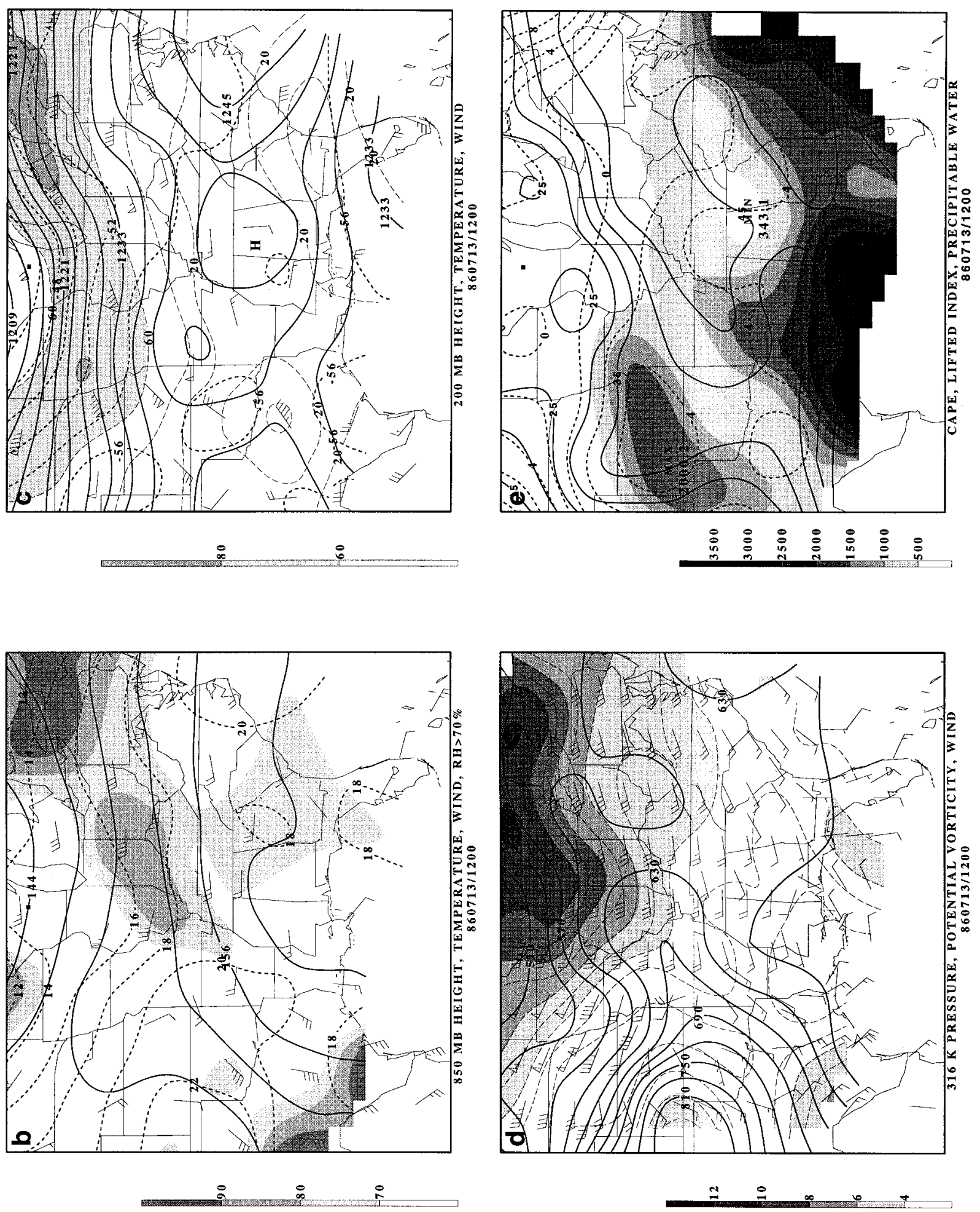


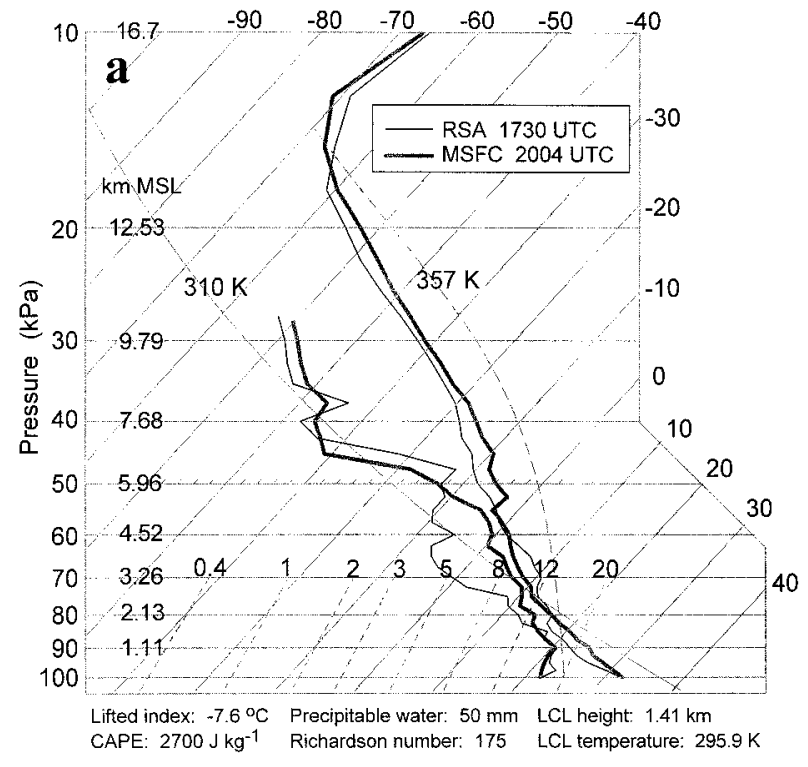

FIG. 4. (a) Soundings plotted on on a skew $T-\log p$ diagram, taken from RSA at 1730 UTC (thin lines) and from MSFC at 2004 UTC (thick lines). See Fig. 2 for relative locations of RSA and MSFC. The dashed curved line is a saturated adiabat having $\left(\theta_{e}=357 \mathrm{~K}\right)$ computed from average surface conditions and defines the temperature profile of an undiluted surface parcel. The solid line labeled $310 \mathrm{~K}$ is a reference dry adiabat. Parameters listed below the diagram apply to the 1730 UTC sounding. (b) Hodograph for the same soundings as in Fig. 4a. Storm motion refers to the motion of line B, one of the major components of the MCS. Also shown are the orientation of lines $\mathrm{B}$ and $\mathrm{C}$ (Fig. 5c), and the strength and direction of the morning low-level jet from the 1200 UTC RSA sounding.

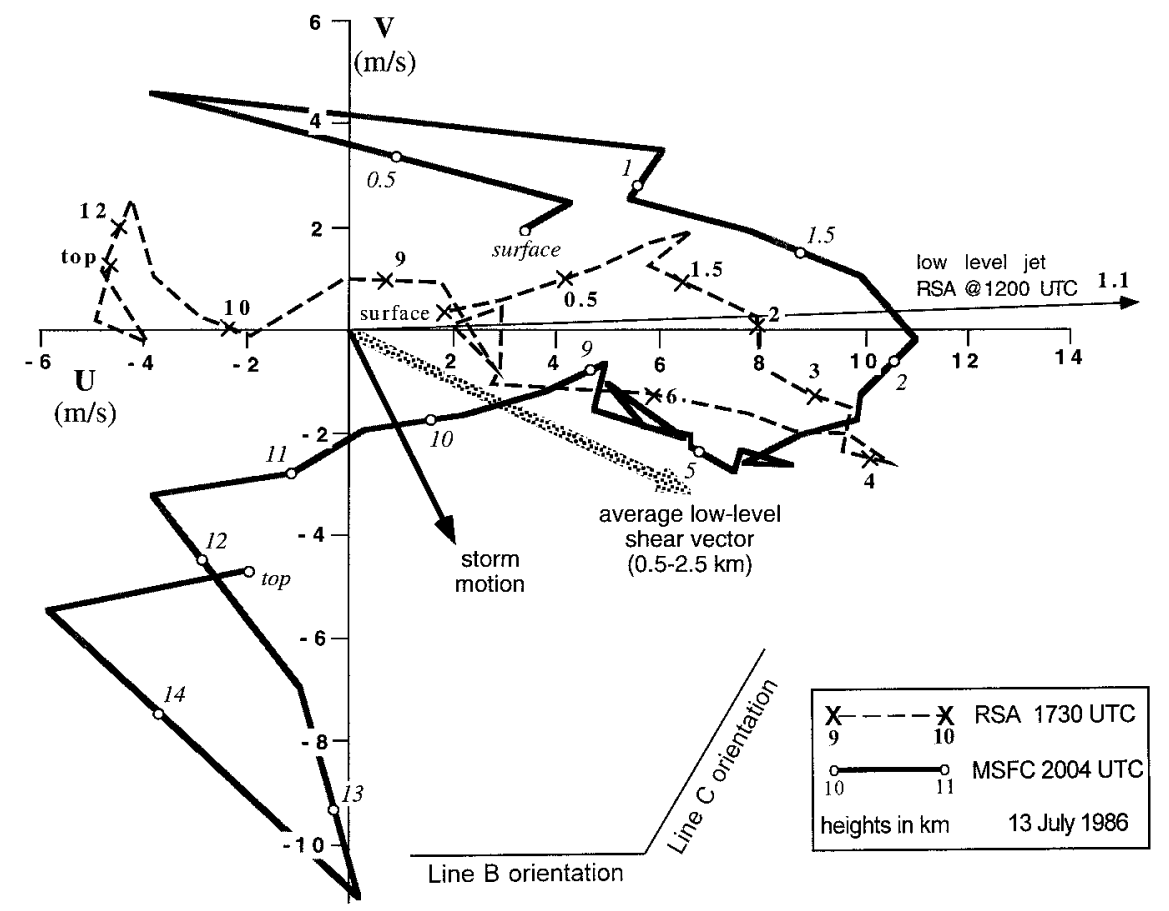

nosed during the latter mature stage for this case (details of mesoscale motions are given in Part II).

\section{b. Wind}

The initial stages of the MCS were associated with very intense convective storms, some of which produced damaging winds at locations marked by "W" in Fig. 7a. Doppler radars (CP-2, CP-4, and FL-2) detected a total of 25 microburst wind shear events ${ }^{5}$ on this day, by far the most active day during COHMEX (Atkins and Wakimoto 1991). The WINDEX, a measure of potential microburst intensity (McCann 1994), was 59

\footnotetext{
${ }^{5}$ A microburst wind shear event is defined by Wilson et al. (1984) as a (divergent) radial velocity differential of at least $10 \mathrm{~m} \mathrm{~s}^{-1}$ over a 4-km radial distance.
} 
(1730 UTC RSA sounding), implying a maximum wind gust of $30 \mathrm{~m} \mathrm{~s}^{-1}$.

Peak wind gusts measured by PAM stations were in the range $12-20 \mathrm{~m} \mathrm{~s}^{-1}$, and the maximum observed gust was $24 \mathrm{~m} \mathrm{~s}^{-1}$ (Atkins and Wakimoto 1991). In consideration of the incomplete sampling of surface winds, these observations are consistent with the WINDEX prediction. Temperature drops associated with convective outflows occasionally exceeded $10 \mathrm{~K}$ (Fig. 8b), near the largest observed during the COHMEX field study. In MCCs, severe weather activity is typically most prevalent during the initial stages (Maddox 1980). In this respect, the 13 July MCS was similar to that of MCC formation.

\section{c. CG lightning}

The total CG count (1800-0100 UTC) within the domain of Fig. 9a was 10335 strikes, $4.0 \%$ of which were positive. This total includes contributions from the initial core MCS plus CG from regions of later development (S, NW, and NE) labeled in Figs. 9 and 14. The ratio of positive to total CG is similar to that of the 10 11 June 1985 squall line (Rutledge and MacGorman 1988), but less than the $9.9 \%$ observed in the 3-4 June 1985 MCS (Holle et al. 1994, Table 1). However, this ratio nearly matches the longer-term value of $4.3 \%$ determined by Reap and MacGorman (1989) for warmseason thunderstorms in the Oklahoma-Kansas region. The peak hourly CG rate was 2400 within the initial MCS (2100-2200 UTC), a value similar to the average peak CG frequency $\left(2700 \mathrm{~h}^{-1}\right)$ determined by Goodman and MacGorman (1986) for the larger MCC (Table 1). During its mature stage, the 10-11 June 1985 squall line exhibited much lower rates of approximately 900 $\mathrm{h}^{-1}$ over a $160000-\mathrm{km}^{2}$ area centered near Wichita, Kansas (Rutledge and MacGorman 1988). Despite its smaller size, the MCS herein was an efficient generator of lightning, both in terms of hourly rate and CG storm totals.

\section{MCS structure and evolution}

This section presents analyses of radar, GOES satellite, surface mesonet, and CG data to document the evolution and structural characteristics of this MCS and its component clusters.

\section{a. Overview}

An overview of the evolving structure of this MCS over the 1800-0100 UTC period is presented in Figs. 10-13. Three stages of MCS evolution are defined in Fig. 11. The developing stage (1800-2100 UTC) represents the period of growth prior to formation of extensive anvil and associated stratiform precipitation (Fig. 10a). The mature stage (2100-0000 UTC) is marked by the presence of active convection and (ex- panding) stratiform precipitation (Fig. 10b), and the dissipating stage (after 0000 UTC) is characterized by much weaker convection. The beginning of the mature stage, as we have defined it, is marked by a maximum in convective intensity (Figs. 11a,c), and the dissipating stage corresponds to a reduction in the area of the GOES 220-K $T_{b}$ contour (Fig. 11b). The stratiform region was fully developed at the beginning of the dissipating stage.

Figure 12 presents high-resolution $Z_{e}$ (with CG lightning locations superimposed) from the CP-4 radar for the 1900-0000 UTC (developing to mature) period, while Fig. 13 contains GOES IR patterns for the 21000000 UTC (mature) period. Figures 5b-d displayed GOES visible images during the developing stage. In the following, this information is used to describe the general details of the entire MCS and its major components $(\mathrm{A}-\mathrm{C})$ labeled in Figs. 5c,d; 10; 12; and 13.

First echo $(>18 \mathrm{dBZ})$ at $0.5^{\circ}$ elevation from the Nashville (BNA) WSR-57 radar occurred at 1730 UTC. The areas of the $18 \mathrm{dBZ}$ contour at $0.5^{\circ}$ and $2^{\circ}$ elevation expanded to respective maxima of about 12000 and $23000 \mathrm{~km}^{2}$ near 2300 UTC (Fig. 11a), and the areas within the 220- and 240-K IR temperature contours reached 49000 and $64000 \mathrm{~km}^{2}$ (Fig. 11b). The area of $Z_{e}$ contours after this time is unknown since the system moved beyond the BNA maximum recording range of $232 \mathrm{~km}$. At the outer ranges of our analysis domain (Fig. 10), the $0.5^{\circ}$ and $2^{\circ}$ elevation scans intersect the system at low $(2-6 \mathrm{~km})$ and middle levels $(5-11 \mathrm{~km})$, respectively. Therefore, the area of $18-\mathrm{dBZ}$ echo at $2^{\circ}$ is a measure of the area of the precipitating anvil region. This area exhibits a rather distinct increase in slope between 2000 and 2200 UTC, whereas echo area at low levels (i.e., the $18-\mathrm{dBZ}$ contour at $0.5^{\circ}$ ) increases at a constant rate on the average.

This increase in slope of the echo area at $2^{\circ}$ elevation is related to the following observations of convective activity.

- The area of $35-\mathrm{dBZ}$ echo at $0.5^{\circ}$, which is a good measure of the convective rain flux, peaks at 3200 $\mathrm{km}^{2}$ just before 2100 UTC. This area is only $10 \%$ of that determined by Holle et al. (1994) for the convective area of a Great Plains MCS.

- The CG frequency (Fig. 11c) reveals a sharp peak more than 300 flashes per 5 min at 2050 UTC, about the same time as the peak of convective rain flux, as measured by the $35-\mathrm{dBZ}$ echo area at $0.5^{\circ}$.

- Figure 11a shows a subjective estimate of the number of individual convective cores as determined from PPI (plan position indicator) plots of the type shown in Fig. 10. Since a $2.2^{\circ}$ beamwidth (for the WSR -57 radar) at $180-\mathrm{km}$ range is $6.5 \mathrm{~km}$ in diameter, only major convective cores (either large single cores or closely packed aggregates of small cores) are resolved. The peak of 18 occurs near 2040 UTC, which precedes the maximum area of the $35-\mathrm{dBZ}$ contour by 15-20 min, and the peak in CG frequency by $10 \mathrm{~min}$. 

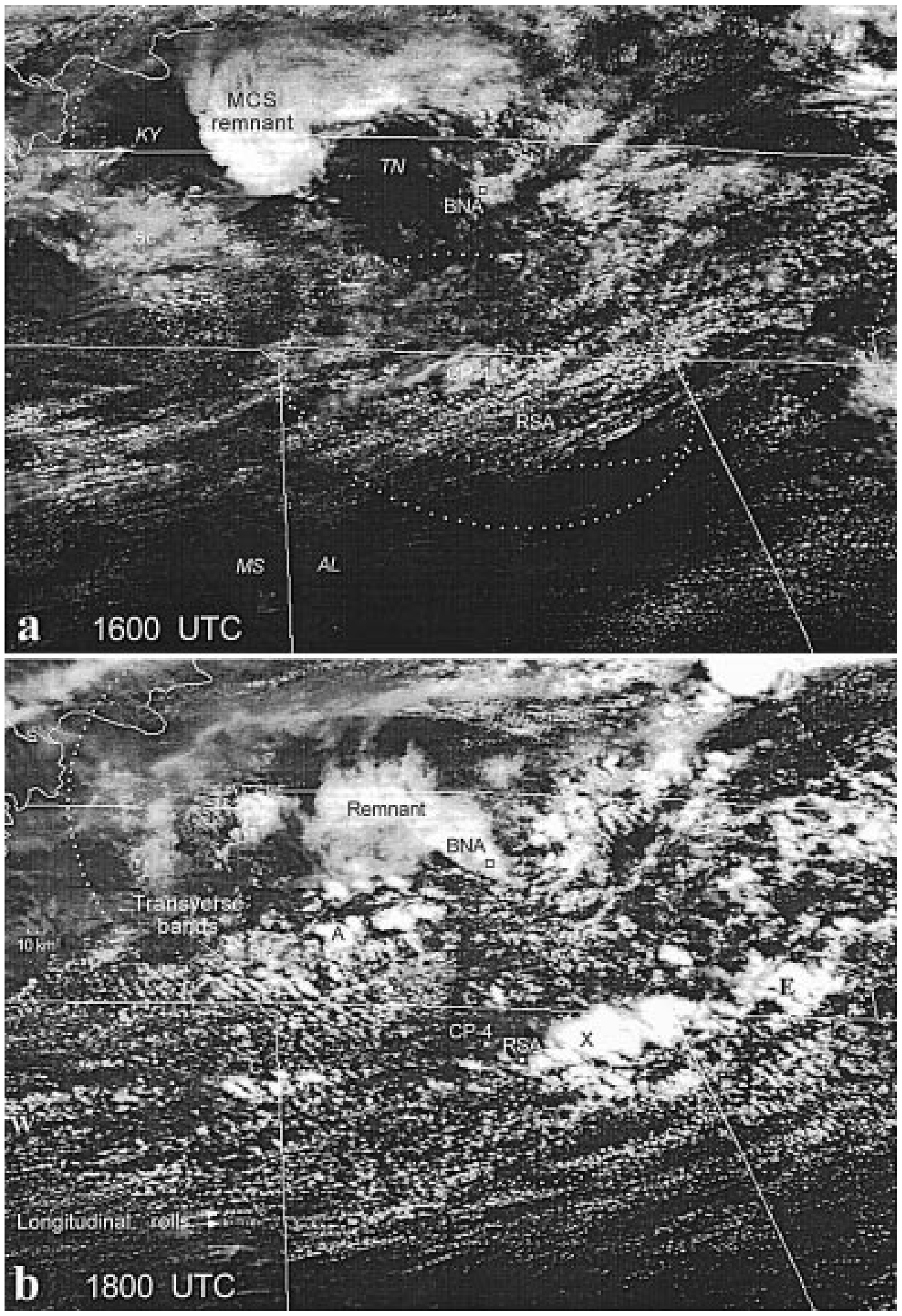

FIG. 5. GOES visible images (1-km resolution) over the COHMEX region at (a) 1600, (b) 1800, (c) 2000, and (d) 2200 UTC 13 July 1986. The maximum ranges of the CP-4 $(115 \mathrm{~km})$ and the BNA WSR-57 $(232 \mathrm{~km})$ radars are indicated by the dotted circles. Sounding locations are RSA and MSFC. The rectangles in (c) and (d) represent the region where average cross sections of $Z_{e}$, GOES IR cloud top, and CG lightning are computed. The letters A, B, C, and $\mathrm{X}$ refer to MCS components defined in the text. 

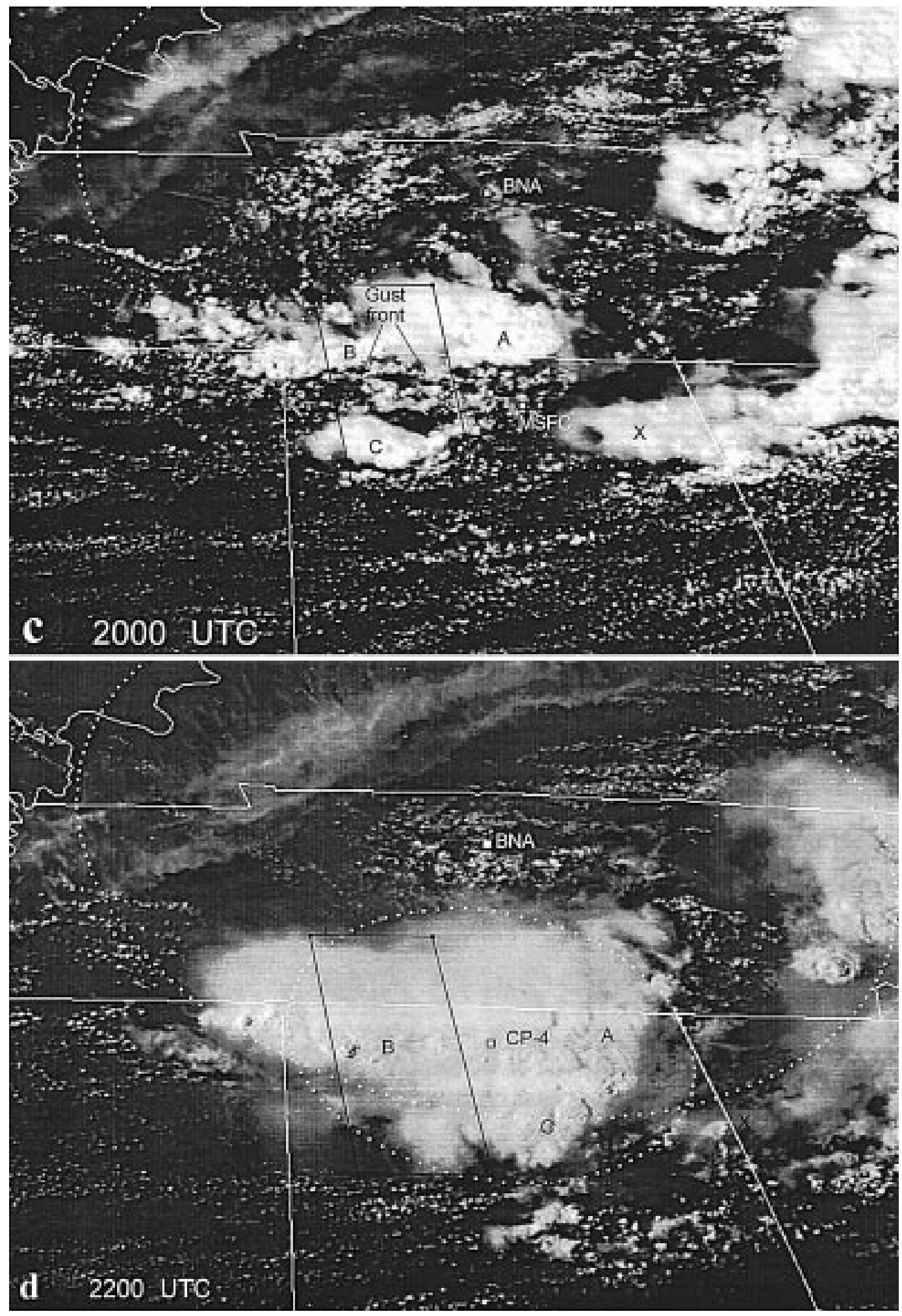

FIG. 5. (Continued) 
Precipitation (mm), 6-12 July 1986

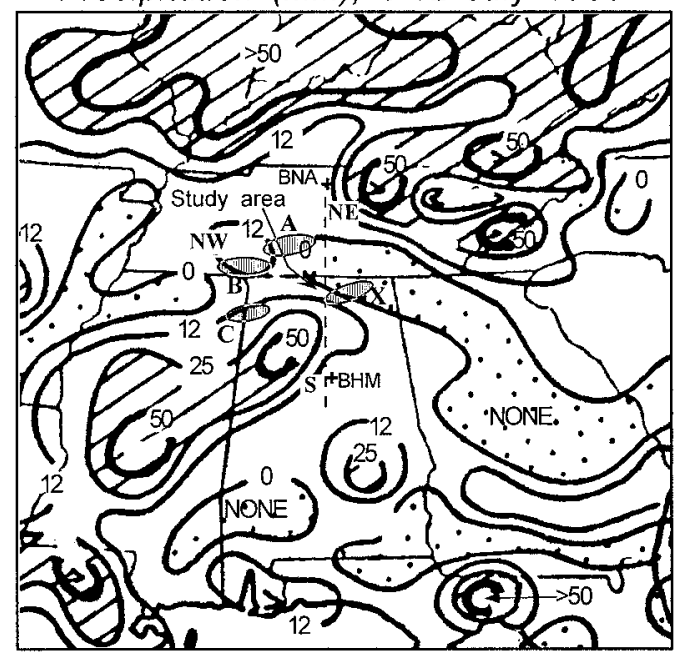

FIG. 6. Rainfall $(\mathrm{mm})$ measured from NWS cooperative sites for the 7-day period 6-12 July 1986. Adapted from the Weekly Weather and Crop Bulletin (1986). Regions of deep convection initiation on 13 July 1986 are shaded and labeled (A, B, C, and X) or labeled (NE, NW, and S).

The decrease in the number of convective cores after 2040 UTC is due to both merger of convective cores and transition to stratiform precipitation, clearly shown in Fig. 10b.

- Minimum blackbody temperature $T_{b}$ values of approximately $200 \mathrm{~K}$, obtained from the GOES IR data (Fig. 11b), were measured between 2100 and 2200 UTC, just after the peaks in $35-\mathrm{dBZ}$ area and CG frequency.

After 2200 UTC cloud-top $T_{b}$ continued to warm (Figs. 13c,d), while beneath the expanding anvil canopy stratiform precipitation exhibited significant expansion between 2200 and 0000 UTC (Figs. 12d-f). By 2350 UTC (near the end of the mature stage) line B, now the major MCS component, had developed a squall-line structure consisting of a convective leading edge and a well-formed stratiform region with $Z_{e}>30 \mathrm{dBZ}$, and a transition region with reduced $Z_{e}$. The expansion of precipitation in this case was thus coincident with a slow warming of anvil cloud top.

The original MCS decayed rapidly after 0000 UTC 14 July as individual convective elements weakened. However, deep convection remained active over adjacent regions after 0100 UTC (Figs. 9b and 14), including (a) the latter stages of secondary development to the south, (b) four redevelopments of intense convection (0000-1000 UTC) near NW along the upshear side of the system, and (c) a brief redevelopment of convection $20-50 \mathrm{~km}$ southeast of CP-4 between 0300 and 0500 UTC.

\section{b. Merger events and MCS intensification}

As noted above in Fig. 11a, cloud-scale mergers promoted intensification of cluster $\mathrm{A}$ and line $\mathrm{B}$, and pro-
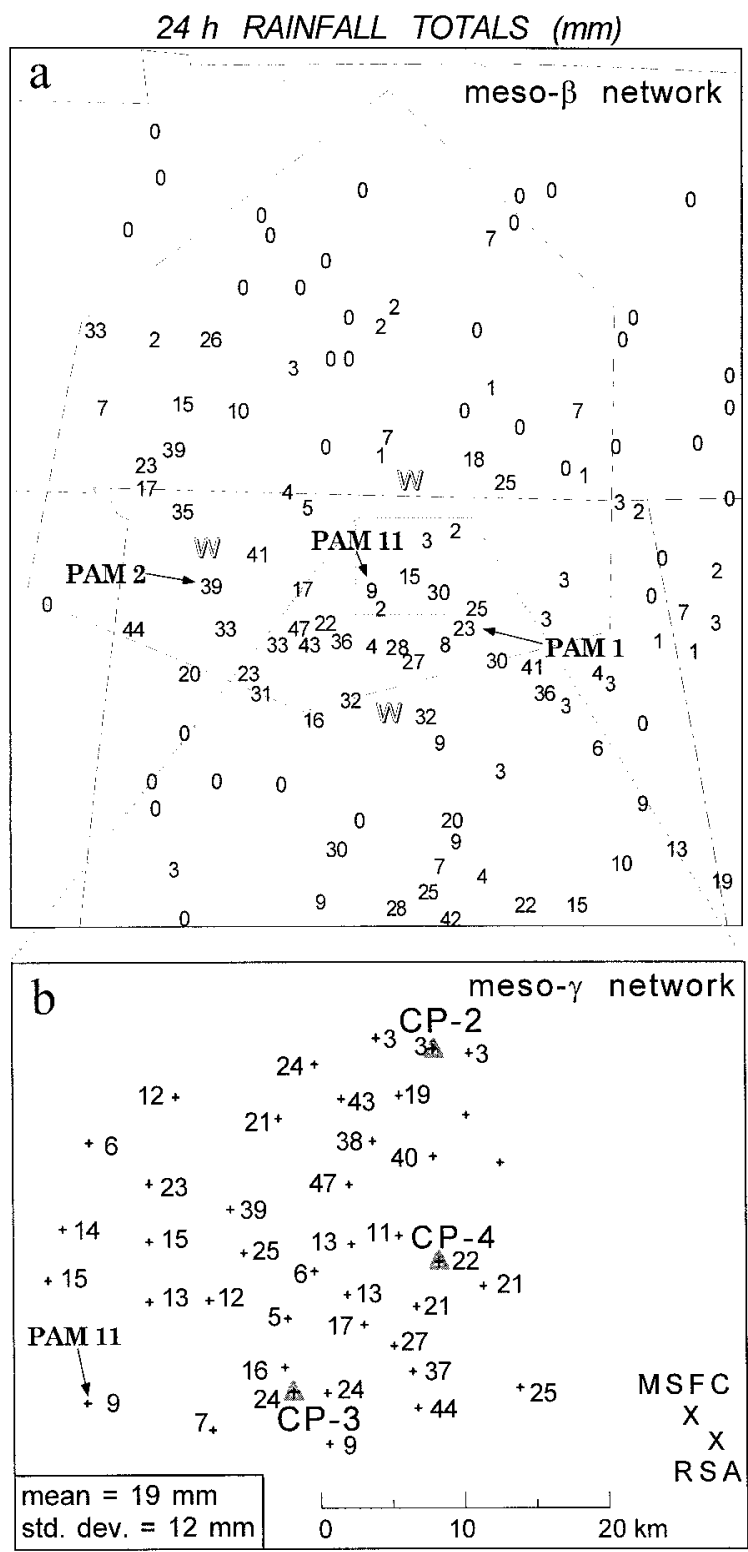

FIG. 7. (a) Rainfall totals over a 24-h time period (ending 1200 UTC 14 July 1986). The dataset includes PAM sites plotted in Fig. 2, plus TVA rain gauge sites, all NWS sites, and Alabama volunteer observer sites. The rainfall totals include contributions from the primary MCS under study, in addition to (i) a secondary, smaller MCS (labeled NW in Fig. 14) that remained anchored over the western portion of this region between 0100 and 1000 UTC 14 July; and (ii) secondary development along the southern limit of the COHMEX domain (Fig. 14). Specific PAM sites $(1,2$, and 11) are identified. Severe weather in the form of damaging winds (between 1900 and 2130 UTC), as documented in Storm Data (1986), are labeled "W." (b) Rainfall totals (24-h period ending 1200 UTC 14 July 1986) plotted in millimeters, obtained from 41 PAM sites over the meso- $\gamma$ network (Fig. 2). Statistics over this network are shown in the lower-left corner.

duced a rapid MCS anvil expansion between 2000 and 2200 UTC. Finescale details of the early MCS merger and expansion are illustrated in the CP-4 low-level reflectivity and CG patterns from 1901-2100 UTC (Figs. 


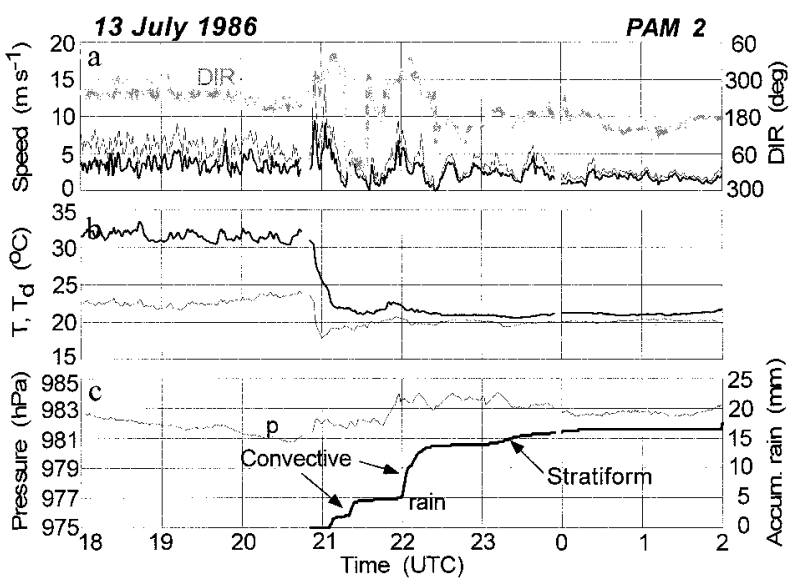

FIG. 8. Time series of 1-min data from the PAM 2 station, whose location is shown in Figs. 2, 7a, and 12a. The two unlabeled traces in (a) are mean wind and peak 1-s value over a 60-s period.

$12 \mathrm{a}-\mathrm{c})$. Over this $2-\mathrm{h}$ period, the MCS evolved from a state consisting of a large number of individual cells ( $~ 90$ at 1901 UTC), to a more organized system consisting of one cluster (A) and two major lines (B and C) by 2100 . Two other minor, intermediate lines of convective cells south of line B at 1959 UTC are denoted as $\mathrm{B}^{\prime}$ and $\mathrm{B}^{\prime \prime}$, the former of which formed along an outflow boundary associated with A (see section 4a). Line $\mathrm{B}^{\prime \prime}$ formed in advance of preexisting outflow boundaries perhaps in the same way as lines B and C by inflection point instability as discussed in section 4 . A merger of lines B-B' $-B^{\prime \prime}$ is apparent by 2100 UTC (Fig. 12c), after which line B assumed an archetypal squall-line structure with trailing stratiform precipitation. This evolution closely parallels the evolution and timing of thunderstorm outflow merger events deter- mined from satellite data over the Southeast (Purdom 1982).

The most impressive merger, associated with an outflow collision over the meso- $\gamma$ network, produced an intermediate, short-lived but very intense cluster of convective cells around CP-4 near 2100 UTC at the intersection among components A-C (labeled "merger event" in Fig. 12c). Although these cells were extremely transient, they produced a burst of CG (Figs. 11c and 12c) and left behind a prominent footprint in the IR signature, namely, the cold tops of $200 \mathrm{~K}$ (Figs. 11b and 13a) that persisted near CP-4 (Figs. 13b,c) even after significant low-level precipitation diminished. Likewise, an earlier merger event within cluster $\mathrm{A}$ is reflected as the $\mathrm{CG}-$ and CG + local maxima near 2010 UTC in Fig. 11c. Consistent with previous merger studies on smaller scales (e.g., Simpson 1980; Westcott 1994), this evidence suggests that the merger increased MCS updraft mass flux and that the enhanced upward flux generated and transported significant precipitation within the anvil region. Similar merger processes were inferred by Goodman and MacGorman (1986) primarily from the observed rapid increase of CG frequency during the development phase of MCCs over Oklahoma.

In the next two sections we examine contrasting characteristics of cluster A and line B, the two major building blocks of this MCS.

\section{c. Structure of cluster A}

Temporal patterns of CG within cluster A were extracted within a $70 \mathrm{~km} \times 70 \mathrm{~km}$ horizontal domain that moved with the system. Cluster A produced abundant $\mathrm{CG}$ consisting of 1705 negative $\mathrm{CG}(\mathrm{CG}-)$ and 172 positive $\mathrm{CG}(\mathrm{CG}+)$ over the 3 -h period from 1820 to 2120 UTC, which represents $40 \%$ and $73 \%$ of the MCS

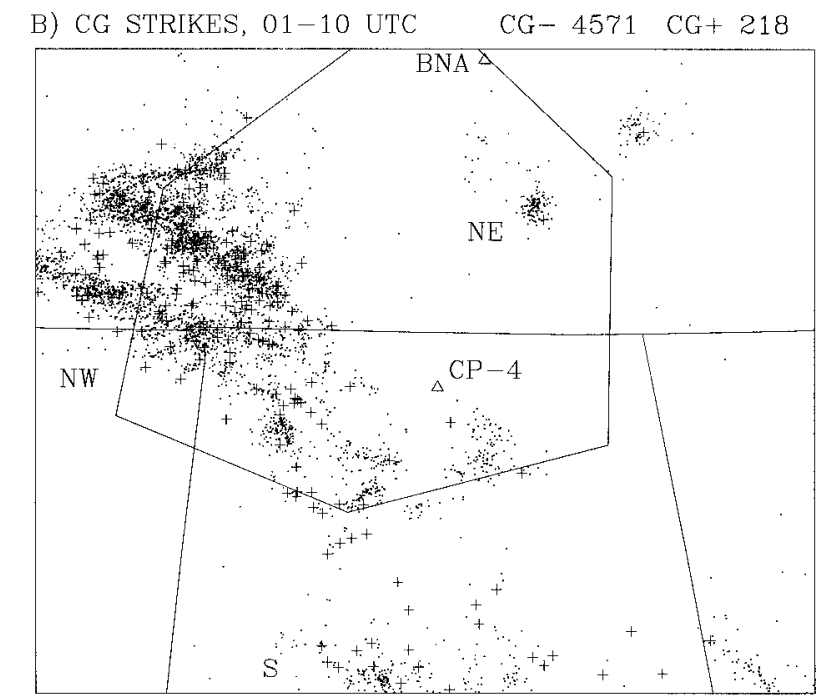

A) CG STRIKES, 18-01 UTC CG-9927 CG 4008

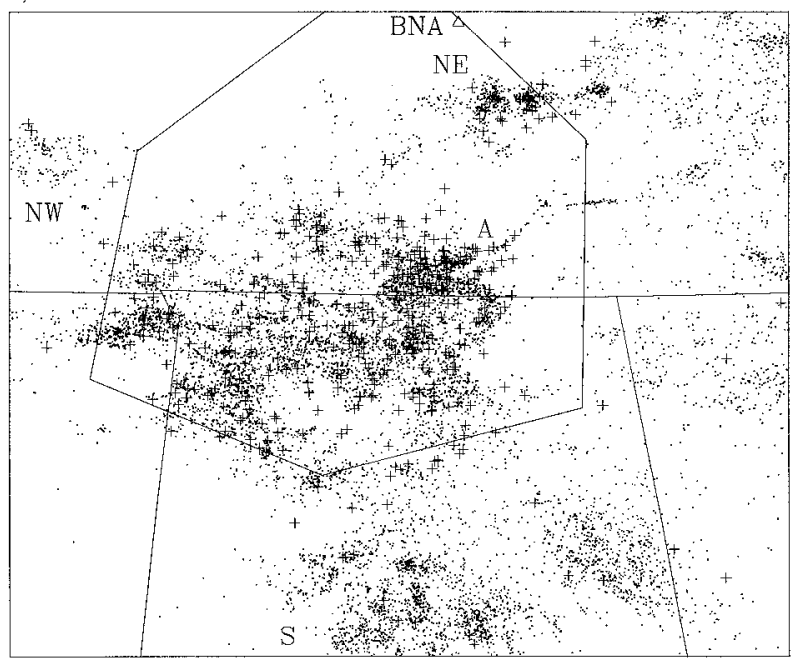

FIG. 9. Plot of cloud-to-ground lightning flashes over the time periods (a) 1800 UTC 13 July to 0100 UTC 14 July 1986 , and (b) 0100 to 1000 UTC 14 July. Dots indicate negative flashes (negative charge transferred to the ground) and "+"s indicate positive flashes. 

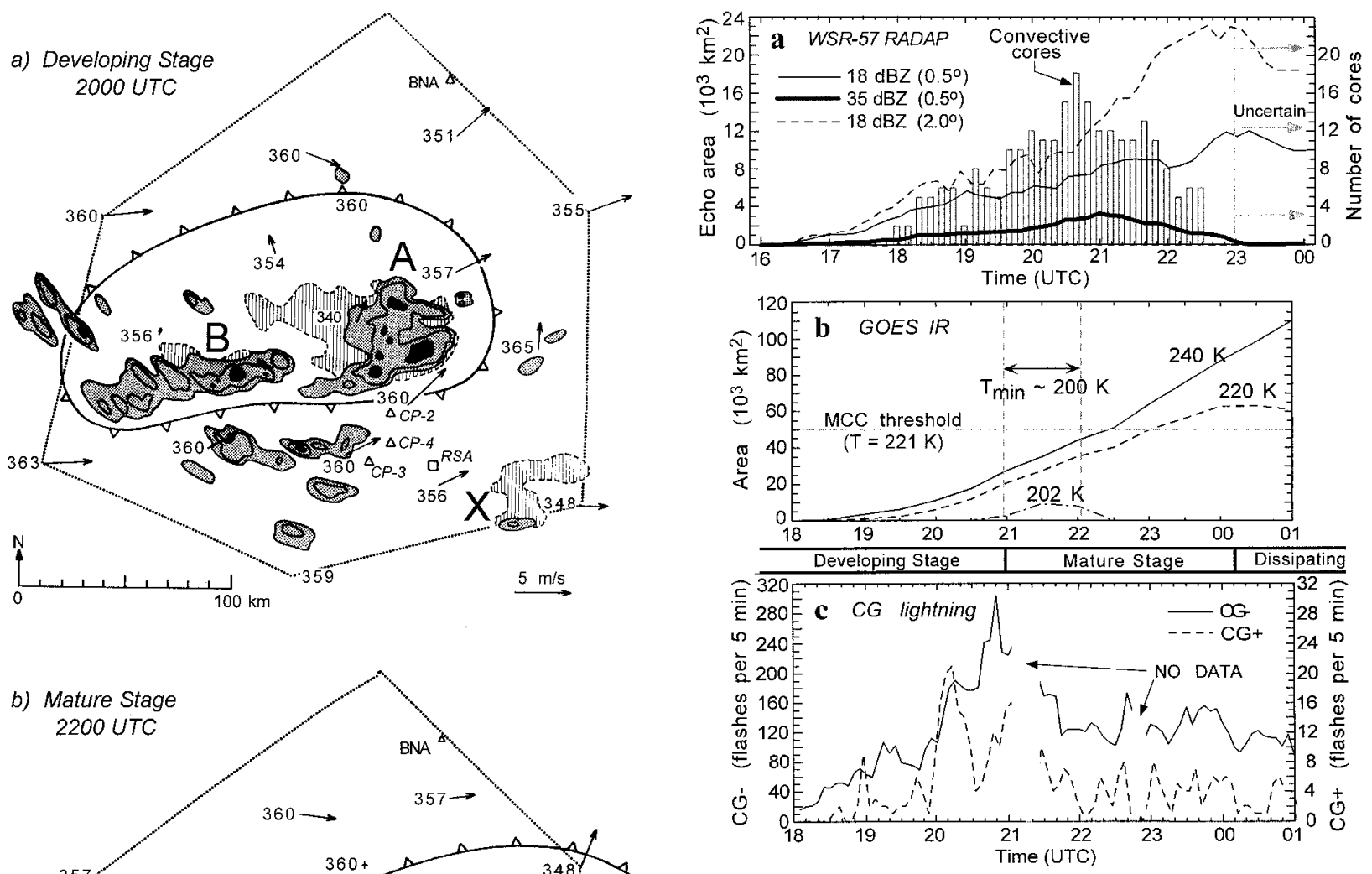

FIG. 11. Time series plots of quantities characterizing the MCS evolution. (a) Parameters derived from the BNA WSR-57 radar, including echo areas exceeding specific reflectivity (18 and $35 \mathrm{dBZ}$ ) thresholds at the elevation angles of $0.5^{\circ}$ or $2.0^{\circ}$. Only areas clearly associated with the MCS are included. After 2300 UTC the MCS moved partly out of the BNA maximum range of recorded data (232 $\mathrm{km})$. The histogram shows the number of major convective cores (i.e., those that are resolvable at the horizontal scales of about $6 \mathrm{~km}$ ), determined subjectively from inspection of PPI plots (e.g., Fig. 10) at an elevation of $0.5^{\circ}$. (b) GOES IR analysis, including areas within blackbody temperature $T_{b}$ contours of 240,220 , and $202 \mathrm{~K}$. The period of observed minimum $T_{b}$ is indicated between 2000 and 2100 UTC. (c) The CG frequency per 5-min interval within the domain of Fig. 9.

For a 20-min period centered on 2005 UTC, positive $\mathrm{CG}$ exceeded $15(5 \mathrm{~min})^{-1}$. This signature largely produces the systemwide CG+ spike near 2010 UTC in Fig. 11c. The coincident peak of the $\mathrm{CG}+$ and $\mathrm{CG}-$ activity is in contrast to observations of the 10-11 June 1985 squall line. In that case the peak in $\mathrm{CG}+$, often taken as a sign of weakening convective activity, occurred $2 \mathrm{~h}$ after the peak in CG- activity (Rutledge and MacGorman 1988). Figure 12b indicates that the CG+ were mostly confined to the intense convective core region during the 1944-2014 UTC period, with only seven CG + flashes located in the developing stratiform region along the northwest flank of the system.

The rather abrupt transition in CG from about 30 to more than 100 per $5 \mathrm{~min}$, and the $\mathrm{CG}+$ spike, were associated with merging of initially loosely packed convective elements into a line of two to three major cells

identified in Fig. 16. From the radar perspective, this and 1940, followed by a rapid increase to more than 100 flashes per 5 min between 2000 and 2045 UTC.

total $\mathrm{CG}-$ and $\mathrm{CG}+$ counts, respectively, over the domain of Fig. 9 during this 3-h period.

The CG time series in Fig. 15a reveals initial inten- 

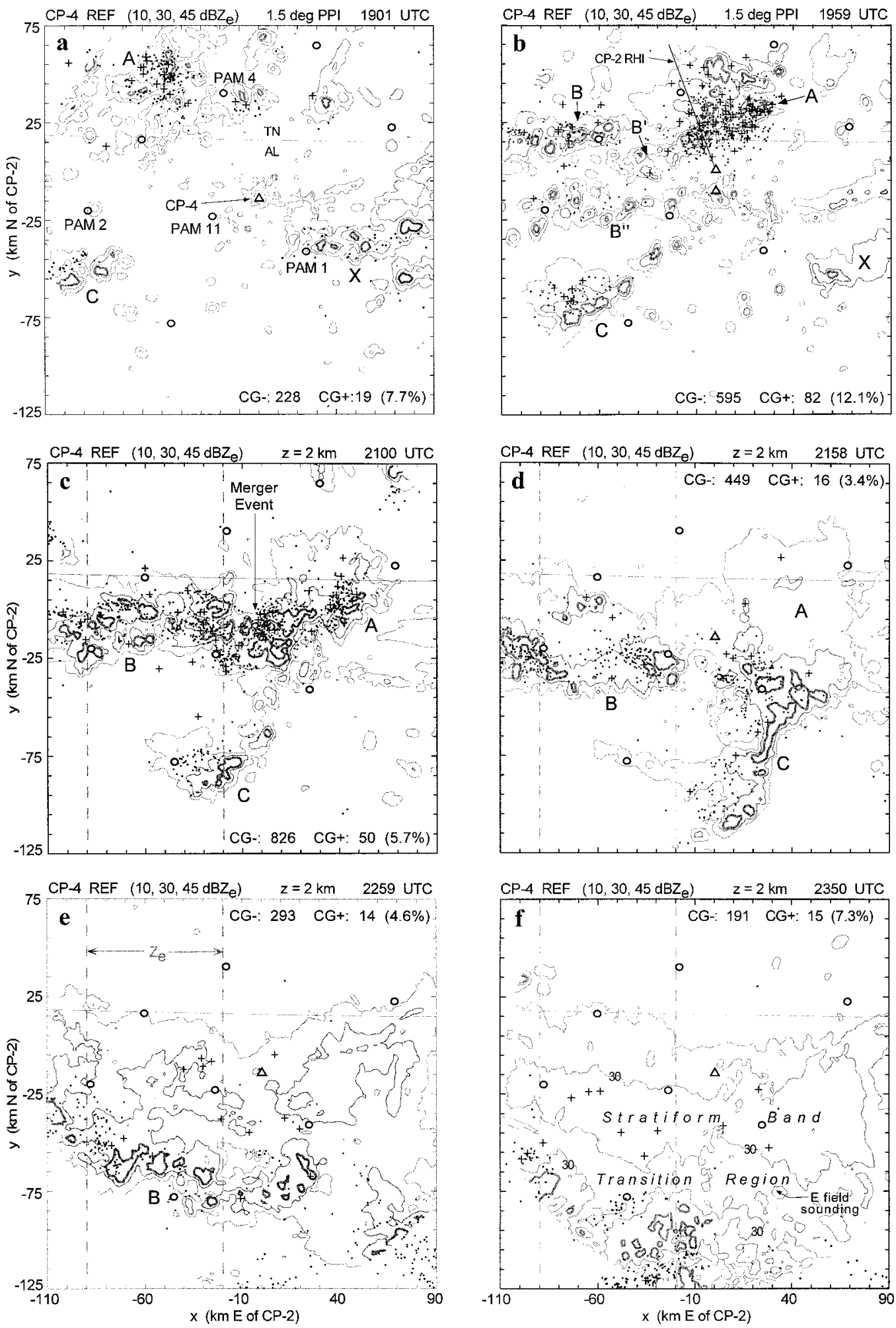

FIG. 12. Horizontal patterns of $Z_{e}$ from CP-4 from $1.5^{\circ}$ PPI scans [(a) and (b)] and from CAPPIs at $2 \mathrm{~km}$ [(c)-(f)] at approximate 1-h intervals for the period 1900-0000 UTC. In all panels $Z_{e}$ contours are drawn for 10, 30, and $45 \mathrm{dBZ}$. The CG flashes occurring over 30min intervals, centered on the radar time, are superimposed. An exception is for (c), which has 9 min of missing CG data (2106-2115 UTC). Dots indicate negative CG and "+" positive CG. Totals for negative and positive CG (CG- and CG+), and the fraction of CG+, are summarized in each panel. In (c)-(f) the east-west distance over which composite $Z_{e}$ patterns are constructed from CP-4 data (Fig. 18) are indicated. Bold circles represent PAM sites, and the triangle depicts the CP-4 location. MCS components (A, B, C, and X) are labeled. 

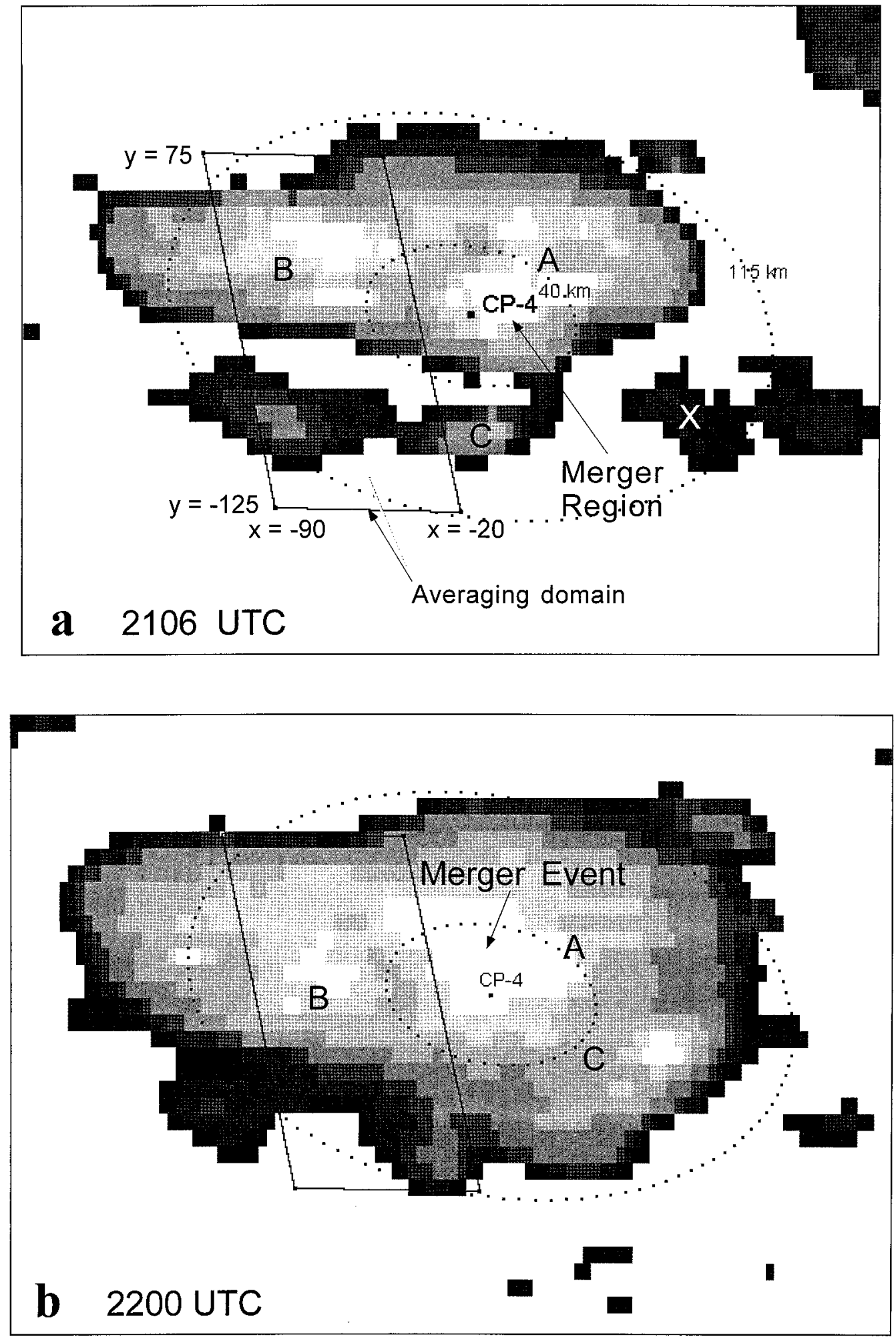

FIG. 13. Enhanced GOES IR satellite images for 1-h time intervals. The enhancement consists of seven gray shades with temperature boundaries as follows: 240 (black), 230, 220, 215, 209, 205, and $202 \mathrm{~K}$ (inner white). Circles define the range limit of CP-4 $(115 \mathrm{~km})$ and the average 40-km range of the CP-4 VAD analyses (Part II). The location of the domain used for east-west averages of $Z_{e}$ (Fig. 18) is depicted by the rectangle. The letter "S" in (c) and (d) denotes secondary development to the south of the original MCS. 

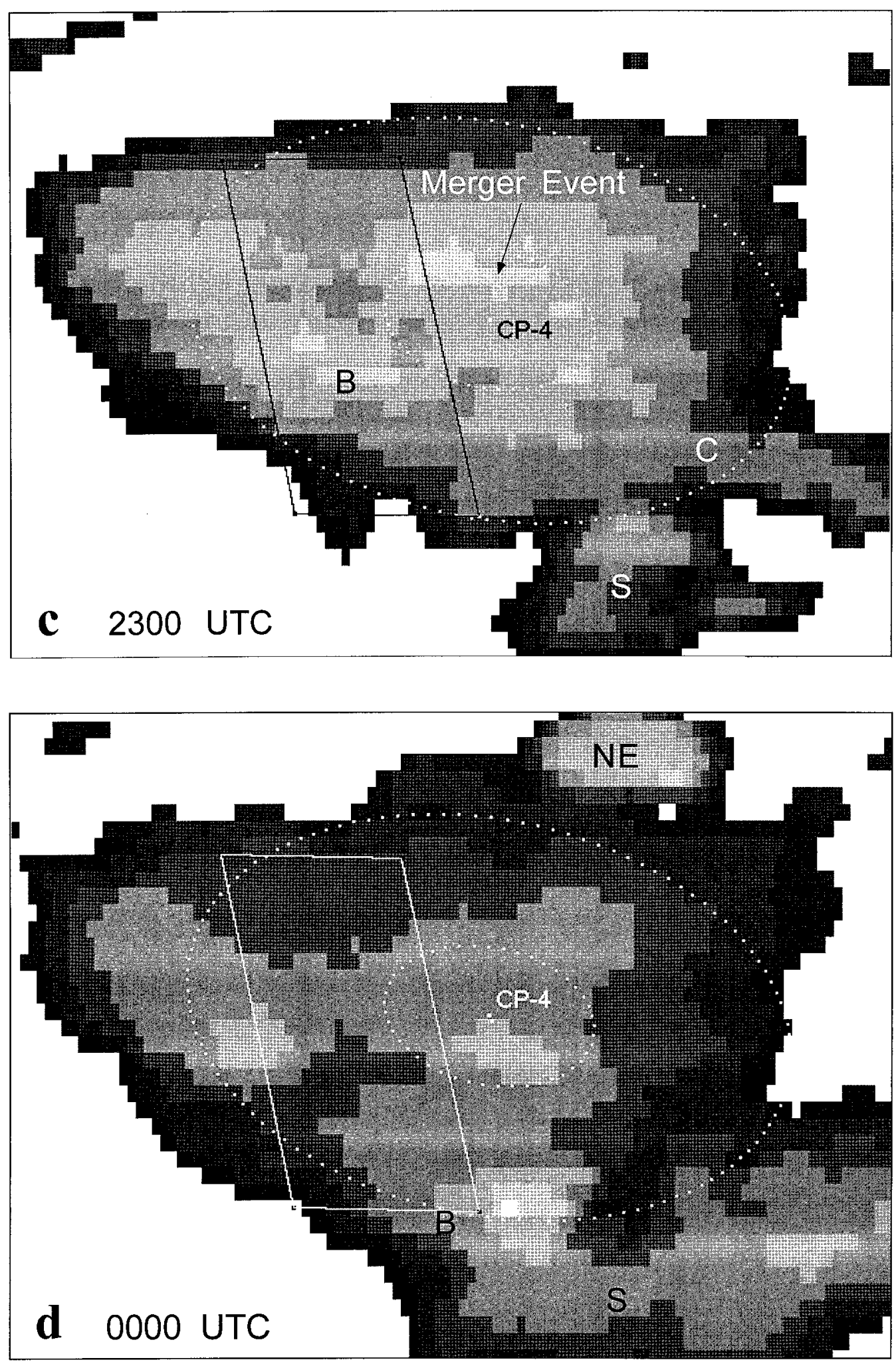

FIg. 13. (Continued) 


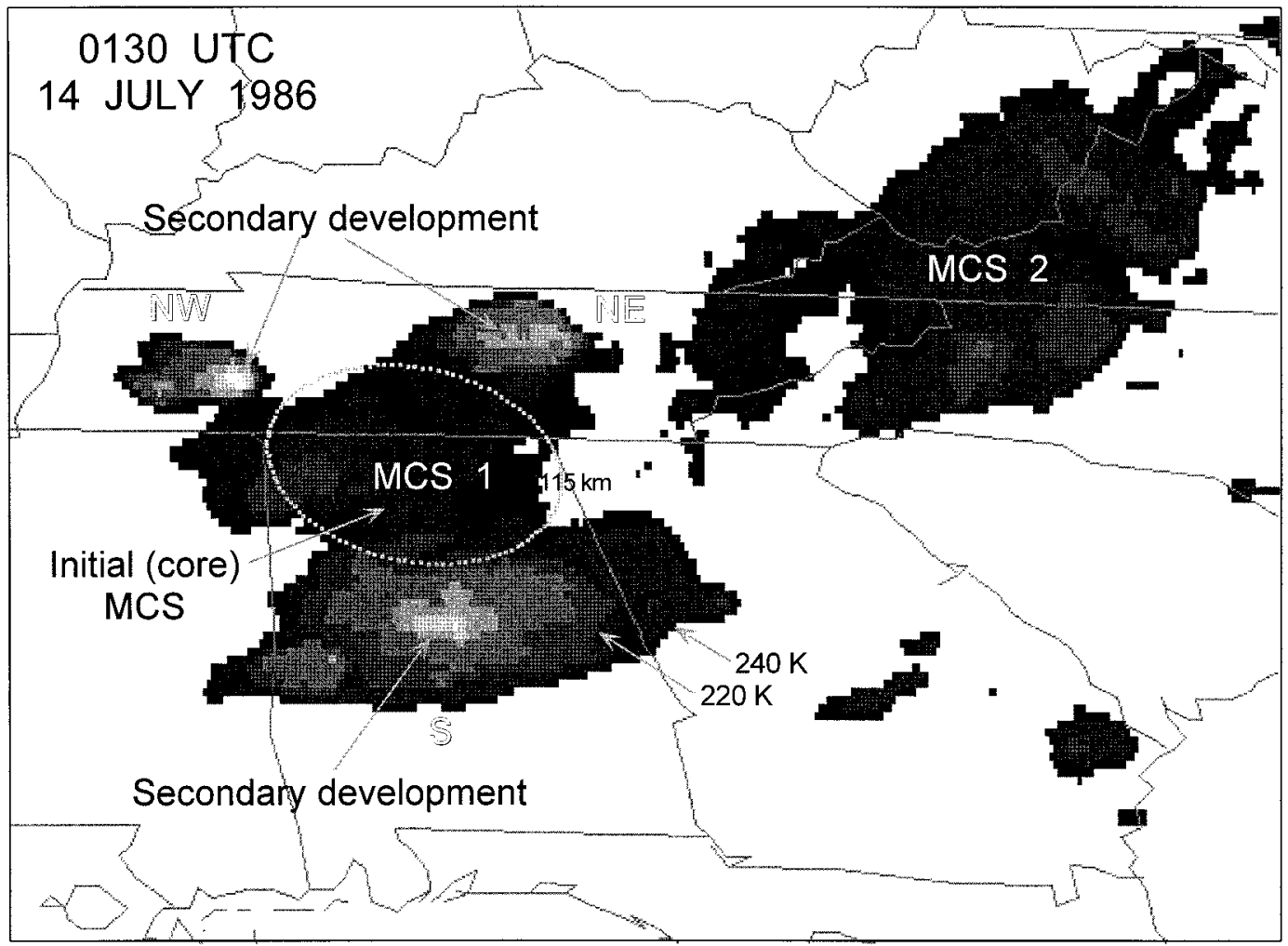

FIG. 14. Enhanced GOES IR image at 0130 UTC 14 July 1986. The enhancement is the same as in Fig. 13. The initial MCS has experienced discrete growth along its NW, NE, and S flanks (labeled). A second system (MCS 2) is identified.

merger process was most significant between 1940 and 2020 UTC. During this intense stage, major cells A1 and $\mathrm{A} 2$ produced several microbursts, one with a maximum recorded wind speed of $24 \mathrm{~m} \mathrm{~s}^{-1}$ (Atkins and Wakimoto 1991). Figure 17 shows an RHI vertical sec- tion through cell A1 at 2006 UTC. The echo top extends to $17 \mathrm{~km}$ above ground level AGL, about $3 \mathrm{~km}$ above the equilibrium level (Fig. 4a), $Z_{e}$ peaks at $59 \mathrm{dBZ}$, the 40- (50-) $\mathrm{dB} Z_{e}$ contour reaches $\sim 15(12) \mathrm{km}$, and strong divergence of $V_{r}$ near cloud top $\left(\sim 50 \mathrm{~m} \mathrm{~s}^{-1}\right.$ over $\left.5 \mathrm{~km}\right)$
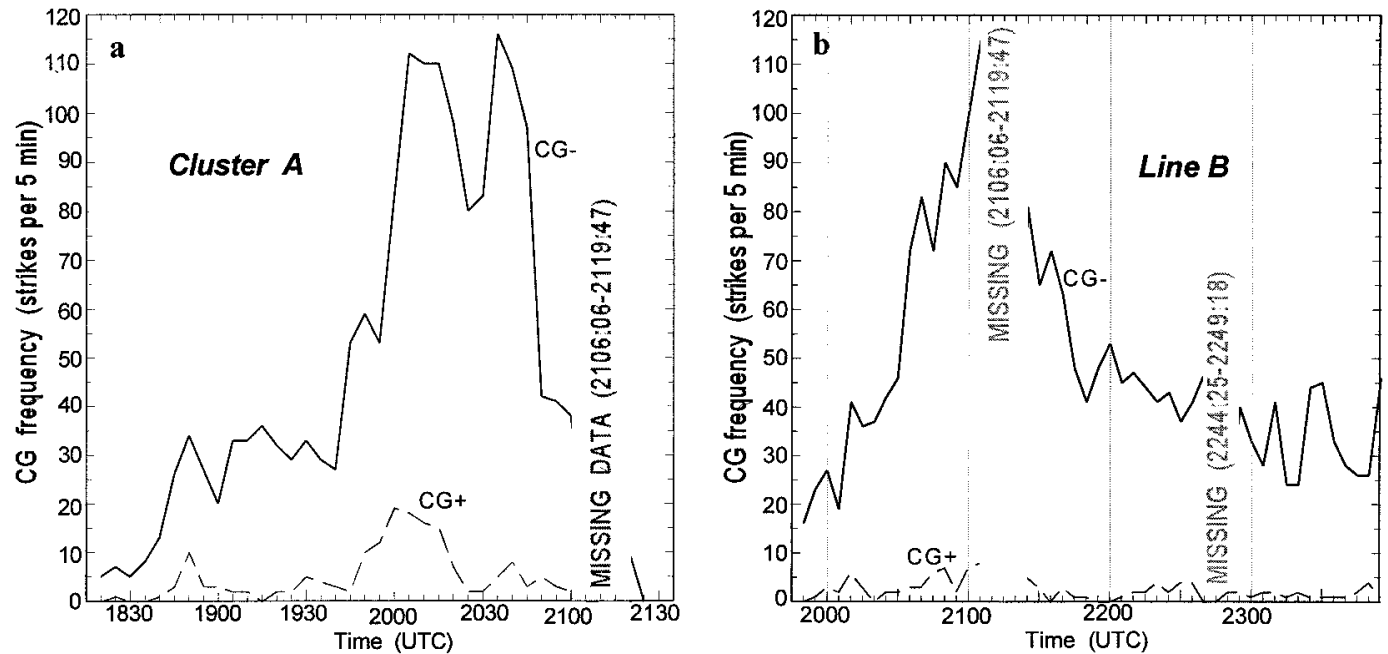

FIG. 15. Time series of CG counts per 5-min interval computed for (a) cluster A over a $70 \mathrm{~km}$ by $70 \mathrm{~km}$ domain following the system, and (b) the segment of line B over the interval $-90<x<-20 \mathrm{~km}$, as defined in Figs. 5c,d; $12 \mathrm{c}-\mathrm{f}$; and $13 \mathrm{a}-\mathrm{d}$. 


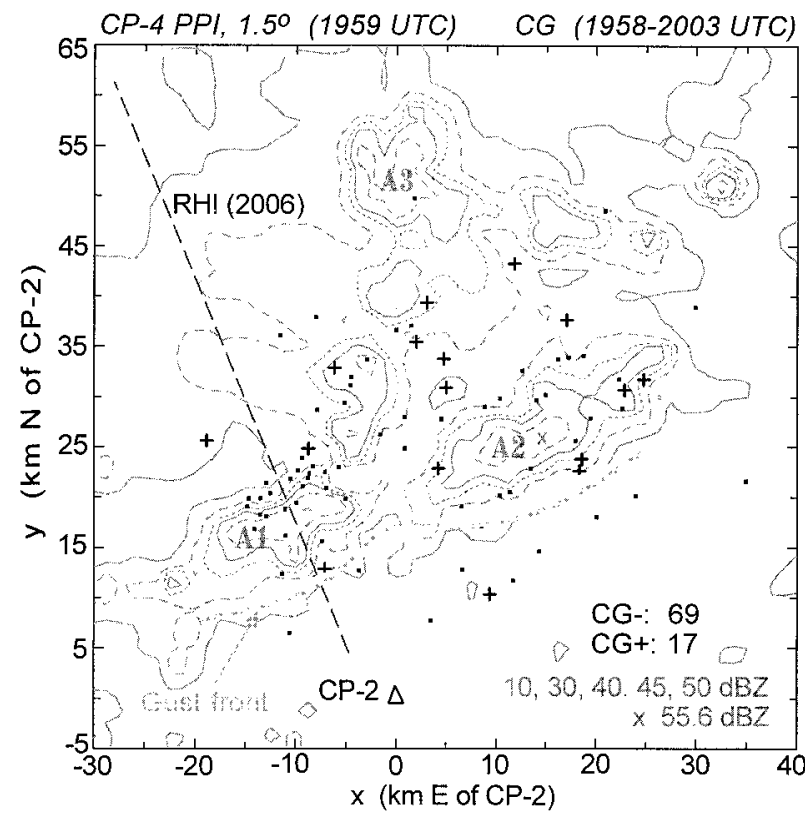

FIG. 16. Contours of $Z_{e}$ (gray) from CP-4 at 1959 UTC, and CG strikes over the 5-min interval 1958-2003 UTC. The time-corrected, relative location of the CP-2 RHI of Fig. 17 is given by the dashed line.

indicates strong updrafts within this cell. The presence of differential reflectivity $Z_{\mathrm{DR}}$ in excess of $2 \mathrm{~dB}$ (not shown) indicates a prominence of rain at low levels, although small hail is suggested by the depressed $Z_{\mathrm{DR}}$ values and enhanced $X$-band attenuation (not shown) in this region.

In this case, the enhanced CG+ were associated with very intense convective elements exhibiting very strong upper-level divergence and associated anvil formation. Doppler radar data support the hypothesis that $\mathrm{CG}+$ were initiated by horizontal displacement of upper-positive charge during rapid anvil expansion. This finding is consistent with patterns found by Stolzenburg (1994), in which a preponderance of $\mathrm{CG}+$ was associated with storms having high echo tops and large hail, both of which tend to be associated with strong upper-level divergence (e.g., Nelson 1983). These observations indicate that $\mathrm{CG}+$ can occur near the core of intense storms without the presence of large hailstones, which MacGorman and Burgess (1994) infer is an important mechanism by which positive charge is transported to lower levels.

Visible GOES imagery also depicts rapid development of intense convection in advance of A between 1930 and 2000 UTC. Some of these incipient cells are apparent to the southeast of A in Fig. 12a. We hypothesize that this burst of convection increased the area of intense precipitation and thereby increased convectivescale downdraft flux and, hence, mesoscale outflow. This notion is supported by measurements from the University of North Dakota Citation aircraft, which sampled
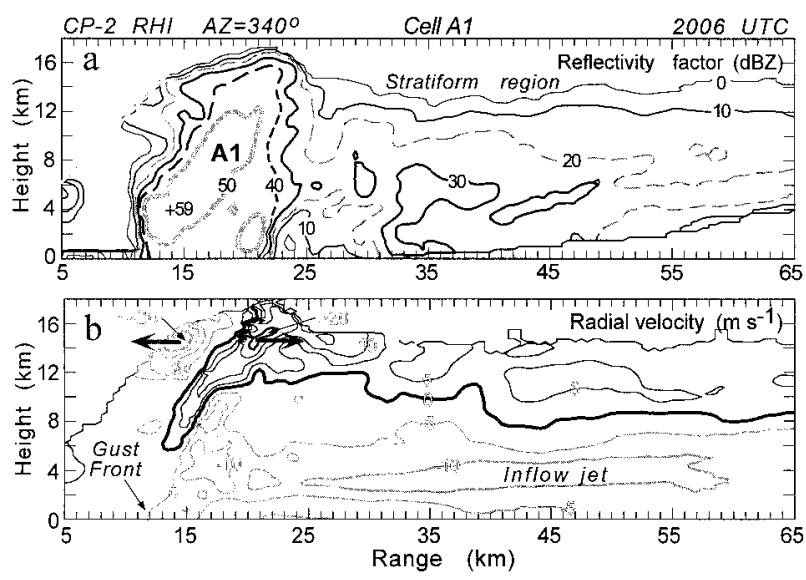

FIG. 17. Vertical section of reflectivity factor $Z_{e}$ and radial velocity $V_{r}$ through an intense convective cell of cluster A, obtained from an RHI scan from CP-2. The location of this section is shown in Figs. $12 \mathrm{~b}$ and 16. (b) Negative (approaching) $V_{r}$ is depicted by the gray contours. Given the $5 \mathrm{~m} \mathrm{~s}^{-1}$ south-southeastward MCS motion, the zero storm-relative contour corresponds to the $-5 \mathrm{~m} \mathrm{~s}^{-1}$ contour as shown.

the ABL in advance of cluster A between 1900 and 2130 UTC. A strong mesoscale outflow was measured at approximately $300 \mathrm{~m}$ AGL beginning near 2020 UTC. Northwesterly winds were measured at $20 \mathrm{~m} \mathrm{~s}^{-1}$ after this time, and blowing dust was observed over bare fields below the aircraft. These measurements indicate a strong southeastward surge of outflow winds and the associated gust front after 2000. This surge corresponds to the rapid demise of cluster A near 2045 UTC, a behavior opposite to that of line B.

\section{d. Structure of line B}

\section{1) ANALysis TeChNIQUe}

The relation between cloud-top and $Z_{e}$ patterns within line $B$ is elucidated with north-south vertical sections of $Z_{e}$ averaged over an east-west segment of the line. The averaging domain for this analysis $(70-\mathrm{km}$-wide swath in the east-west direction) is indicated by the dashed lines in Fig. 12 and the rectangles drawn in Figs. $5 \mathrm{c}, \mathrm{d}$ and 13. This region was selected because of good radar coverage of line B during the period of stratiform precipitation development. The motivation is to detail the formation and evolution of precipitation within the stratiform region and to quantify the relation among $Z_{e}$, the evolving cloud-top surface, and CG distributions.

Reflectivity factor data were averaged in linear units according to

$$
\overline{\mathrm{dB} Z_{e}}=10 \log \left(\sum 10^{\mathrm{dB} Z_{e i} / 10}\right),
$$

where the $\mathrm{dBZ}_{e i}$ are the measured equivalent reflectivity factor at fixed $y$ and $z$ coordinates, the summation is in the east-west direction, and $N$ is the number of points. 
The CG counts over the same $70-\mathrm{km}$ swath were summed within discrete $10-\mathrm{km}$ bins along the $y$ direction for 10-min intervals centered on specific analysis times. This information is represented by histogram plots depicting both positive and negative $\mathrm{CG}$.

GOES IR data were averaged over the same horizontal mesoscale domain as $Z_{e}$. Approximate corrections for viewing angle projection of cloud top were applied. The conversion of brightness temperature $T_{b}$ (assumed to be blackbody) to height used the 2004 UTC MSFC sounding and the equivalent potential temperature of a parcel along a pseudoadiabat originating from the surface.

Height errors originating from the conversion of $T_{b}$ to height will generally be small since most $T_{b}>203$ $\mathrm{K}$, that is, the tropopause level of $14.8 \pm 0.2 \mathrm{~km}$, below which the lapse rates are highly negative and are about $80 \%$ of the dry-adiabatic lapse rate within the 10-14$\mathrm{km}$ AGL layer. Other sources of error are possible. Deep convection may lift the tropopause, cooling it temporarily (e.g., Fovell et al. 1992). Also, IR cooling of the cloud top becomes important over the anvil around sunset at 0055 UTC (e.g., Churchill and Houze 1991), and a spreading, aging anvil becomes optically less thick, such that the upwelling radiation is sampled from an increasingly deep layer below the physical cloud top. However, errors due to all these factors are generally less than a few hundred meters, with the exception of deep convective cores that are not well sampled by the $8-\mathrm{km}$ IR resolution. The resultant product is a series of north-south vertical planes displayed in Fig. 18.

\section{2) Evolving PATterns OF $Z_{e}$ AND CLOUd TOP}

The averaged vertical sections in Fig. 18 reveal the formation of a squall-line structure (e.g., Houze et al. 1990; Weisman et al. 1988; Fovell and Ogura 1988) consisting of a convective line on the leading (south) edge and an expanding, trailing stratiform region. At 2057 UTC two separate convective regions are apparent, and the stratiform precipitation to the north is largely above the melting level. This dual convective core structure (at 2057 and 2258 UTC) illustrates the importance of discrete propagation along the gust front produced by the more intense convective elements that compose the second line (see Fig. 12 for horizontal mappings at 2 -km height). The gust front appears to propagate southward faster $\left(\sim 10 \mathrm{~m} \mathrm{~s}^{-1}\right)$ than either any convective element in the MCS, or the MCS as a whole. The fact that the average IR top lay below the average $Z_{e}$ top indicates the presence of strong cells within the line. The averaging technique defined by Eq. (1) is heavily weighted by the presence of high-reflectivity cores, whereas cloud top involves averaging of more uniform quantities. As time progresses, stratiform precipitation expands both aloft and at the surface, and the cloud-top topography becomes progressively more smooth. The initial development of stratiform precipitation between
2100 and 2200 UTC (3-4 h after convective initiation) is obscured by the presence of some convective cores in the trailing region (Figs. 12d and 18b,c), which inflates the average $Z_{e}$. The dissipating convection shown in Figs. 18b,c ahead of the main convection corresponds with the rear part of line $\mathrm{C}$ in Figs. 12c,d.

By 2258 UTC a well-developed stratiform region with a prominent radar bright band had become established (Fig. 18d). The emergence of this stratiform precipitation appears to result from in situ intensification of $Z_{e}$, as hypothesized by Yuter and Houze (1995b,c). Figure 10 supports this notion. As the stratiform region intensified around 2258 UTC, the adjacent convective region weakened and widened in the $y$ direction. The widening and weakening of the convective region is particularly pronounced between 2258 and 2350 UTC, as shown if Figs. 18d-f (see also Figs. 12e,f). This decline is consistent with the motion of line $\mathrm{B}$ into an environment stabilized by line $\mathrm{C}$ (see Figs. 12c and $18 b, c)$.

Figure 18 also illustrates the evolution of cloud and echo top $\left(5 \mathrm{dBZ}_{e}\right)$ within the stratiform region. Two patterns deserve mention.

- Highest (coldest) cloud tops tend to be located rearward of the convective line over stratiform anvil, a pattern seen at 2130, 2157, and, especially, 2350 UTC. Only at 2258 and perhaps at 2057 UTC are highest tops associated with the convective line. Zipser (1981) has previously noted that convective lines within mature to dissipating MCSs are located near the gradient of $T_{b}$ and not coincident with lowest $T_{b}$ values.

- While at 2057 UTC the echo top coincides with the IR cloud top or exceeds it (due to linear averaging of $Z_{e}$ ), by 2350 UTC the echo top has descended 1-2 $\mathrm{km}$ below the IR top. The rate of cloud-top sinking (as inferred from GOES IR warming) over the stratiform region was computed at $0.2 \mathrm{~m} \mathrm{~s}^{-1}$ between 2200 and 2400 UTC. Hydrometeor settling is particularly pronounced over the stratiform region during the 2258-2350 period. This sinking behavior is in contrast to the increasing vertical gradient in $Z_{e}$ (particularly between values of 5 and $20 \mathrm{dBZ}_{e}$ ) within the anvil at upper levels, and the presence of weak mesoscale ascent there (Part II).

\section{3) LightNiNG BEHAVIOR}

Figure $15 \mathrm{~b}$ shows a high time resolution $\mathrm{CG}$ time series over the region $-110 \mathrm{~km}<x<-20 \mathrm{~km}$ during the intense period of line B. In order to capture intense convection beyond the maximum range of $\mathrm{CP}-4$, this domain extends $20 \mathrm{~km}$ farther west than that used in the $Z_{e}$ and GOES IR averages. The total CG frequency increases at a nearly linear rate from $20(5 \mathrm{~min})^{-1}$ at 1950 UTC to $120(5 \mathrm{~min})^{-1}$ at 2105 UTC. A transient intense phase near 2100 is followed by an exponential decline through 2350 UTC. This temporal behavior dif- 
fers from that of cluster A, which exhibited a slow buildup followed by a rapid decline (Fig. 15a). We take this to imply different dynamical processes between these two components, for example, the outflow in A was stronger (section 6c) and moved in a different direction, such that vorticity of inflow and outflow was more imbalanced (Rotunno et al. 1988), assuming the 1730 UTC wind profile in Fig. $4 \mathrm{~b}$ is valid for the inflow of each region.

The evolution of CG with respect to the evolving composite $Z_{e}$ fields shown in Fig. 18 covers the period from the initial intense convective line to the mature stratiform phase that was accompanied by much weaker deep convection. As shown in the histogram of each panel in Fig. 18, total CG frequency decreases from 372 flashes per $30 \mathrm{~min}$ (over the $70-\mathrm{km}$ east-west swath) during the early intense convective line phase at 2057 UTC to 129 flashes per $30 \mathrm{~min}$ by 2350 UTC. Other noteworthy features over this $3 \mathrm{~h}$ period include the following.

- The north-south distance interval of CG activity doubles from $50-60 \mathrm{~km}$ at 2057 to $110 \mathrm{~km}$ at 2350 UTC, consistent with the broadening of the convective line and emergence of stratiform precipitation (Figs. 12f and 18f).

- At the start of this period, $\mathrm{CG}+$ flashes are basically mixed with $\mathrm{CG}$ - flashes within and immediately adjacent to convective cores. This was the pattern for cluster A (during the spike in $\mathrm{CG}+$, Fig. 12b) and has been noted in a squall line (Rutledge and MacGorman 1988).

- $\mathrm{CG}+$ flashes emanate in the developing trailing stratiform region at $2157 \mathrm{UTC}$, near the time of most substantial development of the bright band. By 2258, $\mathrm{CG}+$ were essentially separated from the $\mathrm{CG}-$ in the weakening convective region, forming a bipole of approximately $50-\mathrm{km}$ length, much smaller than the typical value of 100-200 km in larger MCSs (e.g., Rutledge and MacGorman 1988). This behavior is corroborated by an electric field sounding (released at 2340 UTC from the location indicated in Fig. 12f), which indicated positive charge above the bright band, a feature also observed in the trailing stratiform region of an Oklahoma MCS (Schuur et al. 1991). In our case, the bipole appears in concert with stratiform precipitation development and is most prominent when the stratiform region is well developed. In contrast to the 10-11 June squall line, the $\mathrm{CG}+$ frequency does not increase as the stratiform precipitation area approaches a maximum, perhaps due to the smaller area of stratiform precipitation in our case.

- The CG within dissipating convection (adjacent to the stratiform region) over the interval $115<y<-65$ $\mathrm{km}$ is still negative at $2350 \mathrm{UTC}$, yet the precipitation distribution is transforming from convective to stratiform.

\section{Discussion}

We begin by summarizing similarities and differences between this system and the typical, larger MCS and MCC.

\section{Similarities}

- The line-relative low-level shear vector is similar to that of the strongly classifiable systems examined by Houze et al. (1990).

- Severe weather was most prominent during the MCS development phase.

- Upscale growth was accomplished by outflow interactions and associated cloud mergers.

- Stratiform precipitation formed in the trailing flank, and a transition region bridged the convective and stratiform regions during the latter mature MCS stage.

- An inflow jet within the stratiform region formed in conjunction with emergence of stratiform precipitation (discussed in greater detail in Part II).

- Positive CG was associated with the most intense convective cores.

- A CG bipole formed between the convective and stratiform region during the late mature MCS stage.

\section{Differences}

- A distinct front or even weak baroclinic region was not present in the environment, as in the case of MCCs (Maddox 1983; Cotton et al. 1989).

- Deep-layer wind shear was lower (consistent with the preceding statement), and in the presence of moderately large CAPE (2700 $\left.\mathrm{J} \mathrm{kg}^{-1}\right)$, the bulk convective Richardson number was higher (175).

- Upper-tropospheric flow was much weaker than that of the highly classifiable MCS of Houze et al. (1990).

- Precipitation was more variable, and less (0\%-20\%) originated from the stratiform region as opposed to published values of 30\%-40\% for MCCs and larger MCSs (Tao and Simpson 1989).

Some of these and other findings are expanded in the following.

\section{a. MCS evolution and structure}

In contrast to the largely nocturnal character of MCCs, this MCS formed near solar noon and dissipated $7.5 \mathrm{~h}$ later near sunset. Initiation of deep convection occurred within areas displaying enhanced longitudinal rolls and transverse bands, the former having been examined in considerable detail by Fankhauser et al. (1995). This region experienced variations in rainfall during the previous week, and the evolution of morning cloud fields (fog and stratocumulus) suggests that variations in insolation played a role in dictating when and where deep convection was triggered. These observations are consistent with the premise that horizontal variations in surface heat flux produced mesoscale circu- 

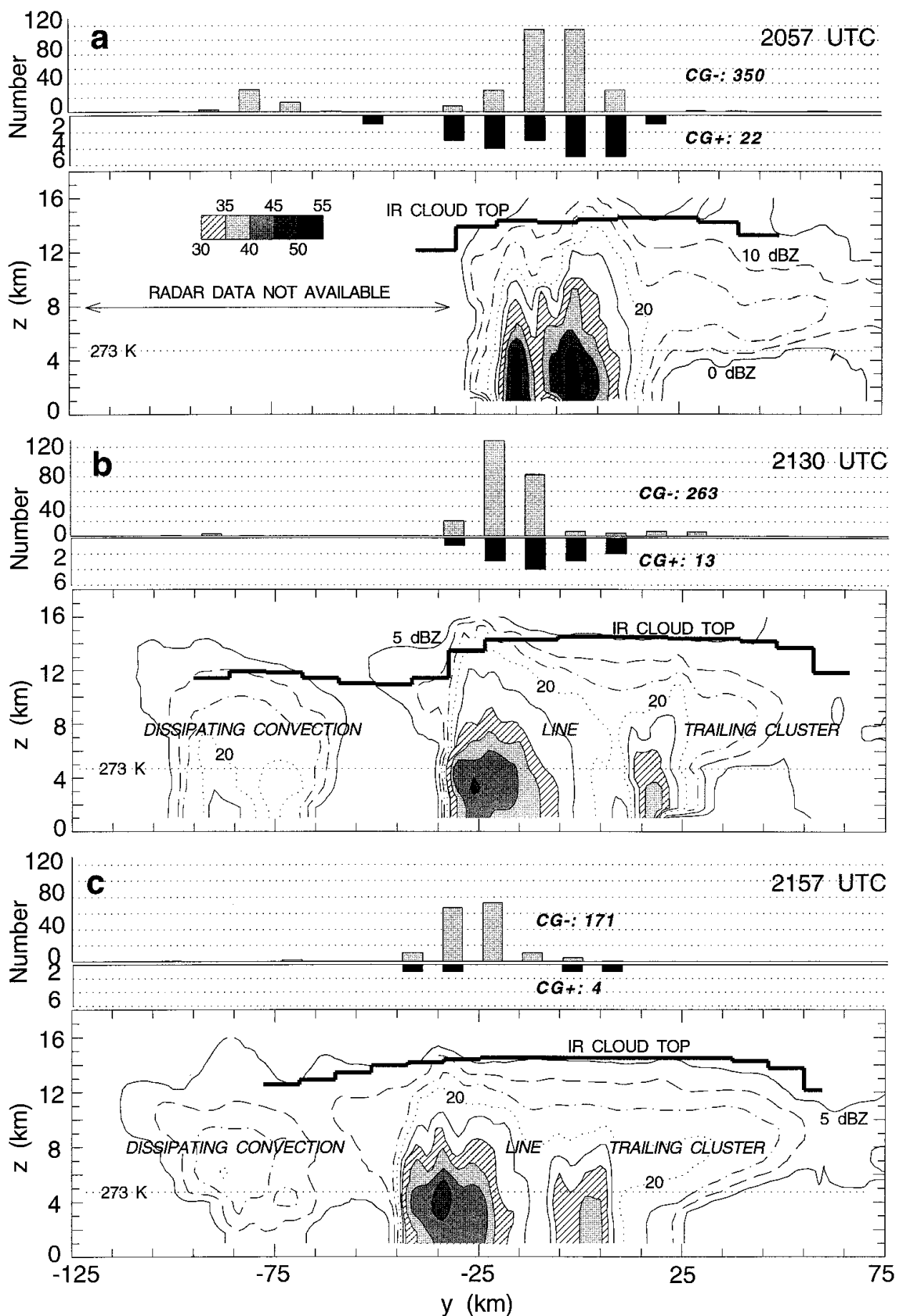

FIG. 18. Analyses of $Z_{e}$ and CG within the major convective line (line B), averaged over the east-west domain indicated in Figs. 5, 12, and 13. The horizontal axis is meridional distance from CP-4, located at $y=-14$. The upper panels depict 30-min lightning counts within $10-\mathrm{km}$ bins along the $y$ axis (note the change in scale between negative and positive CG). In all $Z_{e}$ presentations, (lower panel), the cloud top estimated from averages of GOES IR data is superimposed on the radar data to portray the relation between cloud top and $Z_{e}$, which is contoured every $5 \mathrm{~dB}$ beginning at $5 \mathrm{dBZ}$. This sequence shows the southward progression of the convective line and the development of precipitation within the stratiform region. 

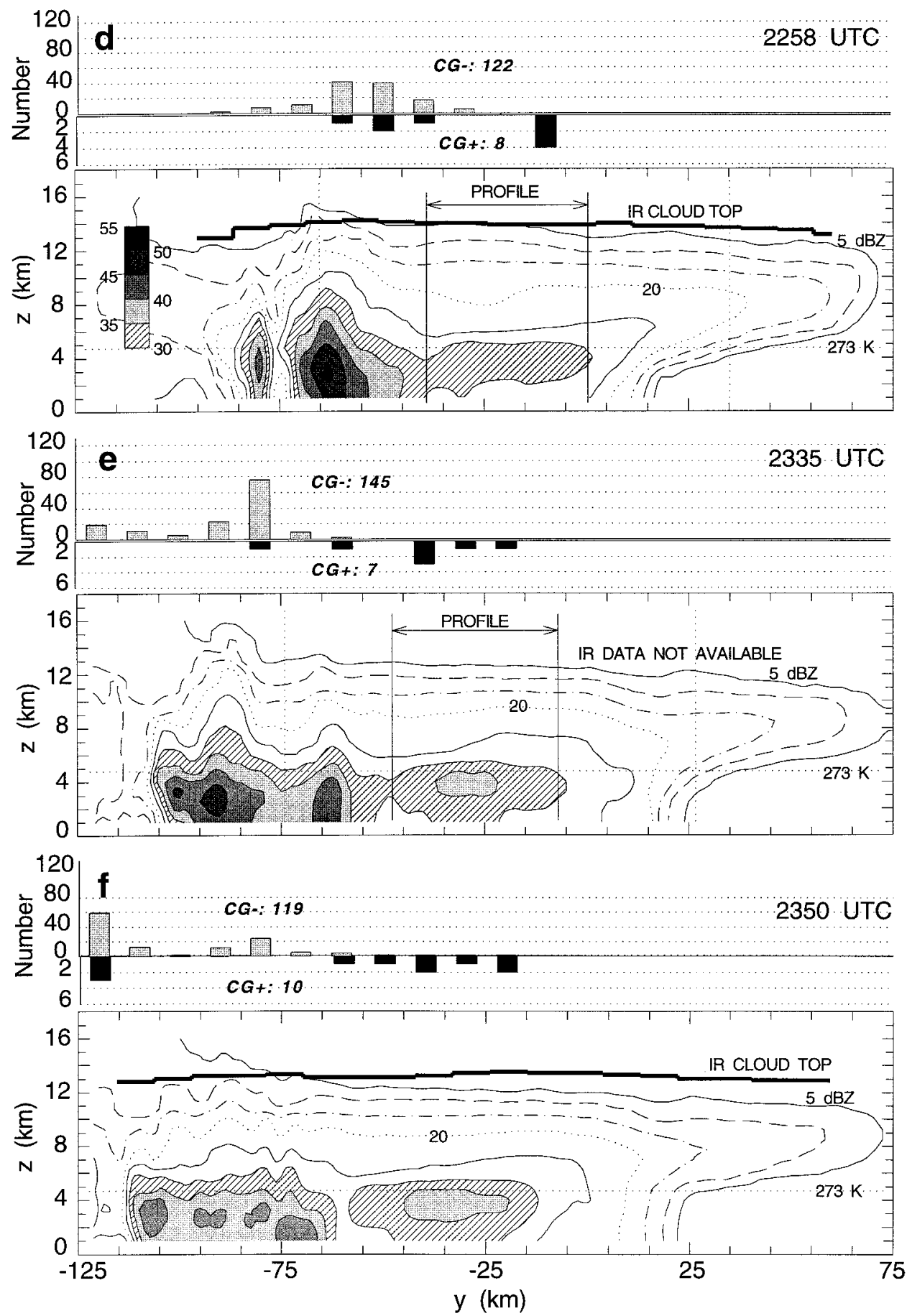

FIG. 18. (Continued)

lations, initiating deep convection in three preferred areas.

During its developing stage, the MCS consisted of three mesoscale components displaying different orientations and characteristics. Convective elements within cluster A assumed a southwest-northeast orientation at maturity, but this component dissipated rapidly as its strong outflow surged ahead of the system. The longerlasting line $\mathrm{B}$, the most significant of the mesoscale components, assumed an east-west orientation parallel to the low-level shear. Line $\mathrm{C}$ was initially parallel but assumed an eventual north-south orientation perpendicular to the shear vector. Despite this more favorable orientation, line $\mathrm{C}$ was not sustained. We note that line 
B experienced the largest low-level relative inflow since its component of motion was more southerly than either A or C. The tangential orientation of convective lines (such as line B) appears to typify environments having a low-level shear vector magnitude less than $5 \mathrm{~m} \mathrm{~s}^{-1}$ (Barnes and Seikman 1984; Alexander and Young 1992). In our case the low-level shear is larger, about $8 \mathrm{~m} \mathrm{~s}^{-1}$. We conjecture that the orientation of line $\mathrm{B}$ is related to the west-east orientation of longitudinal rolls that appeared to initiate both line B and its merger companion B" (see Fig. 5b).

The MCS expanded rapidly via new generation along individual and intersecting outflow boundaries, both within the individual components $\mathrm{A}-\mathrm{C}$ and between them. The period of most intense convection corresponded to a merger of intense convective components within cluster $\mathrm{A}$, line $\mathrm{B}$, and linear convection $\left(\mathrm{B}^{\prime \prime}\right)$ in advance of line $B$. The observed intensification and rate of expansion of precipitation within the trailing anvil region of line $\mathrm{B}$ was most rapid near the time of maximum activity of deep convection. Some of this precipitation growth appears to have been generated within the stratiform region as convective elements dissipated in a time-dependent fashion [in a manner similar to the particle fountain concept advanced by Yuter and Houze (1995c)] as opposed to being transported directly from the region of active deep convection. As the stratiform region further evolved to a 50-100-km-wide structure exhibiting a prominent bright band, the cloud top descended, slowly in terms of IR brightness temperature $\left(\sim 0.2 \mathrm{~m} \mathrm{~s}^{-1}\right)$ and more rapidly in terms of $Z_{e}$. While the vertical gradient of reflectivity factor increased during this process, partly due to leveling of the cloud-top topography, the distance between the IR cloud top and the 0 -dBZ level increased by a factor of $3(800-2400$ $\mathrm{m})$ over a 2 -h period.

\section{b. CG behavior}

Despite having an area of $40 \%$ and a duration of $60 \%$ that of the average MCC, this MCS exhibited a peak hourly CG flash rate of about 2400, comparable to an average peak value of 2700 (for $10 \mathrm{MCCs}$ ) determined by Goodman and MacGorman (1986). The system total of about $10000 \mathrm{CG}$ is about $50 \%$ that for the MCC average totals. Positive CGs (CG+'s) were most prevalent around the intense convective cores that displayed rapid growth and high, diverging echo tops. The presence of $\mathrm{CG}+$ was associated with strong divergence of the anvil and not the presence of large hail at the surface. Cluster A, for example, exhibited a peak $\mathrm{CG}+$ rate of $20(5 \mathrm{~min})^{-1}$ (which was $18 \%$ the total CG rate) during its most intense phase. While this fraction of $\mathrm{CG}+$ is not unusually high when compared to Great Plains storms (Stolzenburg 1994), it is consistent with the accumulating observations that storms (including supercells) in the Southeast tend to have higher CG rates overall, but lower fractions of $\mathrm{CG}+$ (Buechler et al. 1996).

As stratiform precipitation formed within the trailing region of the MCS (mostly within line B) $\mathrm{CG}+$ flashes emerged within the stratiform region, but only after the bright band and low-level precipitation had become well established. The bipole length in this case was quite short at $50 \mathrm{~km}$, which corresponds to the distance between the respective cores of the stratiform and convective regions. In comparison, bipole lengths of 100$200 \mathrm{~km}$ are found in larger MCSs (Rutledge and MacGorman 1988; Stolzenburg 1990; Engholm et al. 1990; Hunter et al. 1992; Rutledge and Petersen 1994). While the observed flow showed weak front-to-rear flow at upper levels, both the development of precipitation and the $\mathrm{CG}+$ within the stratiform region occurred in situ, thus supporting the in situ charging mechanism discussed by Engholm et al. (1990) and Rutledge and Petersen (1994).

\section{Conclusions}

The following hypotheses and conclusions represent some key issues regarding this, and perhaps other, small MCSs.

1) Given the synoptically benign character of the prestorm environment, we hypothesize that variability in surface heat flux produced cloud-initiating, solenoidally driven mesoscale circulations. In addition, we speculate that the organization of deep convection (longitudinal rolls and transverse bands) was largely controlled by the spatial variations of earlier stratiform clouds and shallow convection. Thus, details of the ABL and associated variable surface fluxes (e.g., as controlled by antecedent precipitation and cloud shading) are important and require accurate parameterization in mesoscale models (e.g., McNider et al. 1994).

2) The large variability in rainfall was a product of the intense, slow-moving, transient convective cells. These facets are related to the high Richardson number (175) of the environment, which is much higher than that of the typical MCC environment.

3) Because deep convection during the MCS mature stage was not sustained, the fraction of stratiform precipitation was lower $(<20 \%)$ than that of larger, longer-lived systems documented in the literature. The lower yield of stratiform precipitation may be related to inferred decreasing trends of updraft mass flux at upper levels due to the progressive weakening of transient deep convection as the MCS matured, which is consistent with the progressive lowering of $Z_{e}$ contours as shown in Fig. 18.

4) Mergers of individual and mesoscale outflow boundaries were associated with the most intense convective phase of MCS (as measured by cold cloud tops, echo areas of large $Z_{e}$, and high CG rates) and the 
rapid expansion of precipitation in the anvil region. We hypothesize that growth of MCSs of the type documented here requires the fortuitous merger of several areas of convection.

5) The expansion and intensification of stratiform precipitation in this MCS, which are further quantified in Part II, occurred locally (in situ) and not by advection from the convective region (convective cells had short lifetimes). This same argument supports in situ charging as the mechanism producing $\mathrm{CG}+$ in the stratiform region.

6) The emergence of CG+ around convective cores was associated with strong outflow at high levels within the anvil. This supports the hypothesis that $\mathrm{CG}+$ is facilitated by a tilted dipole, that is, displacement of positive charge at high levels.

Acknowledgments. Simon Paech assisted with the synoptic analysis. This research was supported by NASA under Grant NAG8-654 and by NSF under Grants ATM-8800606 and ATM-9200667. The National Center for Atmospheric Research (sponsored by NSF) provided radar and surface instrumentation, software (RDSS, REORDER, and CEDRIC), and computing resources used to complete this work. Information from the $\mathrm{Ci}$ tation aircraft was provided by the University of North Dakota.

\section{REFERENCES}

Alexander, G. D., and G. S. Young, 1992: The relationship between EMEX precipitation feature properties and their environmental characteristics. Mon. Wea. Rev., 120, 554-564.

Atkins, N., and R. M. Wakimoto, 1991: Wet microburst activity over the southeastern United States: Implications for forecasting. Wea. Forecasting, 6, 470-482.

Augustine, J. A., and K. W. Howard, 1988: Mesoscale convective complexes over the United States during 1985. Mon. Wea. Rev., 116, 685-701.

_ United States during 1986 and 1987. Mon. Wea. Rev., 119, 15751589.

Barnes, G. M., and K. Siekman, 1984: The environment of fast- and slow-moving tropical mesoscale convective lines. Mon. Wea. Rev., 112, 1782-1794.

Biggerstaff, M. I., and R. A. Houze Jr., 1991: Kinematic and precipitation structure of the 10-11 June 1985 squall line. Mon. Wea. Rev., 119, 3035-3065.

Brandes, E. A., 1990: Evolution and structure of the 6-7 May 1985 mesoscale convective system and associated vortex. Mon. Wea. Rev., 118, 109-127.

Brooks, H. E., C. A. Doswell III, and J. Cooper, 1994: On the environments of tornadic and nontornadic mesocyclones. Wea. Forecasting, 9, 606-618.

Brown, R. A., 1980: Longitudinal instabilities and secondary flows in the planetary boundary layer: A review. Rev. Geophys. Space Phys., 18, 683-697.

Browning, K. A., and F. F. Hill, 1984: Structure and evolution of mesoscale convective system near the British Isles. Quart. J. Roy. Meteor. Soc., 110, 897-913.

Buechler, D. B., S. J. Goodman, E. W. McCaul, and K. R. Knupp, 1996: Cloud-to-ground lightning activity within tornadic supercells in the Tennessee Valley. Preprints, 18th Conf. on Severe Local Storms, San Francisco, CA, Amer. Meteor. Soc., 499-503.
Chong, M., P. Amayenc, G. Scialom, and J. Testud, 1987: A tropical squall line observed during the COPT 81 experiment in West Africa. Part I: Kinematic structure inferred from dual-Doppler radar data. Mon. Wea. Rev., 115, 670-694.

Churchill, D. D., and R. A. Houze Jr., 1984: Development and structure of winter monsoon cloud clusters on 10 December 1978. J. Atmos. Sci., 41, 933-960.

, and - 1991: Effects of radiation and turbulence on the diabatic heating and water budget of the stratiform region of a tropical cloud cluster. J. Atmos. Sci., 48, 903-922.

Cotton, W. R., M.-S. Lin, R. L. McAnelly, and C. J. Tremback, 1989: A composite model of mesoscale convective complexes. Mon. Wea. Rev., 117, 765-783.

Engholm, C. D., E. R. Williams, and R. M. Dole, 1990: Meteorological and electrical conditions associated with positive cloudto-ground lightning. Mon. Wea. Rev., 118, 470-487.

Fankhauser, J. C., N. A. Crook, J. Tuttle, L. J. Miller, and C. G. Wade, 1995: Initiation of deep convection along boundary layer convergence lines in a semitropical environment. Mon. Wea. Rev., 123, 291-313.

Fovell, R. G., and Y. Ogura, 1988: Numerical simulation of a midlatitude squall line in two dimensions. J. Atmos. Sci., 45, 38463879.

_, D. Durran, and J. R. Holton, 1992: Numerical simulations of convectively generated stratospheric gravity waves. J. Atmos. Sci., 49, 1427-1442.

Geerts, B., 1998: Mesoscale convective systems in the southeast United States during 1994-95: A survey. Wea. Forecasting, in press.

Goodman, S. J., and D. R. MacGorman, 1986: Cloud-to-ground lightning activity in mesoscale convective complexes. Mon. Wea. Rev., 114, 2320-2328.

Hauser, D., F. Roux, and P. Amayenc, 1988: Comparison of two methods for the retrieval of thermodynamic and microphysical variables from Doppler radar measurements: Application to the case of a tropical squall line. J. Atmos. Sci., 45, 1285-1303.

Hildebrand, P. H., 1978: Iterative correction for attenuation of $5 \mathrm{~cm}$ radar in rain. J. Appl. Meteor., 17, 508-514.

Holle, R. L., A. I. Watson, R. E. Lopez, D. R. MacGorman, and R. Ortiz, 1994: The life cycle of lightning and severe weather in a 3-4 June 1985 PRE-STORM mesoscale convective system. Mon. Wea. Rev., 122, 1798-1808.

Houze, R. A., 1993: Cloud Dynamics. International Geophysics Series, Vol. 53, Academic Press, 570 pp.

— S. A. Rutledge, M. I. Biggerstaff, and B. F. Smull, 1989: Interpretation of Doppler weather radar displays in midlatitude mesoscale convective systems. Bull. Amer. Meteor. Soc., 70, 608-619.

, B. F. Smull, and P. Dodge, 1990: Mesoscale organization of springtime rainstorms in Oklahoma. Mon. Wea. Rev., 118, 613654.

Hunter, S. M., T. J. Schuur, T. C. Marshall, and D. W. Rust, 1992: Electric and kinematic structure of the Oklahoma mesoscale convective system of 7 June 1989. Mon. Wea. Rev., 120, 22262239.

Johnson, R. H., and P. J. Hamilton, 1988: The relationship of surface pressure features to the precipitation and airflow structure of an intense midlatitude squall line. Mon. Wea. Rev., 116, 1444-1472.

Keighton, S. J., H. B. Bluestein, and D. R. MacGorman, 1991: The evolution of a severe mesoscale convective system: Cloud-toground lightning location and storm structure. Mon. Wea. Rev., 119, 1533-1556.

Klimowski, B. A., 1994: Initiation and development of rear inflow within the 28-29 June 1989 North Dakota mesoconvective system. Mon. Wea. Rev., 122, 765-779.

Knupp, K. R., and W. R. Cotton, 1987: Internal structure of a small mesoscale convective system. Mon. Wea. Rev., 115, 629-645. , and V. Chandrasekar, 1993: Estimation of C-band attenuation in heavy rain environments. Preprints, 26th Int. Conf. on Radar Meteorology, Norman, OK, Amer. Meteor. Soc., 543-545.

_ B. Geerts, and J. D. Tuttle, 1998: Analysis of a small, vigorous 
mesoscale convective system in a low-shear environment. Part II: Evolution of the stratiform precipitation and mesoscale flows. Mon. Wea. Rev., 126, 1837-1858.

Leary, C. A., and R. A. Houze, 1979: Melting and evaporation of hydrometeors in precipitation from the anvil clouds of deep tropical convection. J. Atmos. Sci., 36, 669-679.

MacGorman, D. R., and D. W. Burgess, 1994: Positive cloud-toground lightning in tornadic storms and hailstorms. Mon. Wea. Rev., 122, 1671-1697.

Maddox, R. A., 1980: Mesoscale convective complexes. Bull. Amer. Meteor. Soc., 61, 1374-1387.

_ 1983: Large-scale conditions associated with midlatitude, mesoscale convective complexes. Mon. Wea. Rev., 111, 1475-1493.

— D. M. Rodgers, and K. M. Howard, 1982: Mesoscale convective complexes over the United States in 1981: Annual summary. Mon. Wea. Rev., 110, 1501-1514.

Mapes, B. E., and R. A. Houze Jr., 1993: Cloud clusters and superclusters over the oceanic warm pool. Mon. Wea. Rev., 121, 13981415.

Martin, D. W., and A. J. Schreiner, 1981: Characteristics of West African and east Atlantic cloud clusters: A survey from GATE. Mon. Wea. Rev., 109, 1671-1688.

McCann, D. W., 1994: WINDEX-A new index for forecasting microburst potential. Wea. Forecasting, 9, 532-541.

McNider, R. T., A. J. Song, D. M. Casey, P. J. Wetzel, W. L. Crosson, and R. M. Rabin, 1994: Toward a dynamic-thermodynamic assimilation of satellite surface temperature in numerical atmospheric models. Mon. Wea. Rev., 122, 2784-2803.

Miller, D., and J. M. Fritsch, 1992: Mesoscale convective complexes in the western Pacific region. Mon. Wea. Rev., 120, 2978-2992.

Mohr, C. G., and L. J. Miller, 1983: CEDRIC-A software package for Cartesian space editing, synthesis and display of radar fields using interactive control. Preprints, 21st Conf. on Radar Meteorology, Edmonton, AB, Canada, Amer. Meteor. Soc., 569-574.

Nelson, S. P., 1983: The influence of storm flow structure on hail growth. J. Atmos. Sci., 40, 1965-1983.

Nielsen, K. E., R. A. Maddox, and S. V. Vasiloff, 1994: The evolution of cloud-to-ground lightning within a portion of the 10-11 June 1985 squall line. Mon. Wea. Rev., 122, 1809-1817.

Purdom, J. F. W., 1982: Subjective interpretation of geostationary satellite data for nowcasting. Nowcasting, K. A. Browning, Ed., Academic Press, 149-166.

Reap, R. M., and D. R. MacGorman, 1989: Cloud-to-ground lightning: Climatological characteristics and relationships to model fields, radar observations and severe local storms. Mon. Wea. Rev., 117, 518-535.

Rodgers, D. M., and K. W. Howard, 1983: Mesoscale convective complexes over the United States during 1982. Mon. Wea. Rev., 111, 2363-2369.

— M. J. Magnano, and J. H. Arns, 1985: Mesoscale convective complexes over the United States during 1983. Mon. Wea. Rev., 113, 888-901.

Rotunno, R., J. B. Klemp, and M. L. Weisman, 1988: A theory for strong, long-lived squall lines. J. Atmos. Sci., 45, 463-485.

Rutledge, S. A., and D. R. MacGorman, 1988: Cloud-to-ground lightning activity in the 10-11 June 1985 mesoscale convective system observed during Oklahoma-Kansas PRE-STORM project. Mon. Wea. Rev., 116, 1393-1408.

— and cloud-to-ground lightning in the stratiform region of MCSs: Further evidence for in situ charging in the stratiform region. Mon. Wea. Rev., 122, 1760-1776.

, C. Lu, and D. R. MacGorman, 1990: Positive cloud-to-ground lightning in mesoscale convective systems. J. Atmos. Sci., 47, 2085-2100.

Schuur, T. J., B. F. Smull, W. D. Rust, and T. C. Marshall, 1991: Electrical and kinematic structure of the stratiform precipitation region trailing an Oklahoma squall line. J. Atmos. Sci., 48, 825842.

Segal, M., R. W. Arritt, C. Clark, R. Rabin, and J. Brown, 1995: Scaling evaluation of the effect of surface characteristics on potential for deep convection over uniform terrain. Mon. Wea. Rev., 123, 383-400.

Simpson, J., 1980: Downdrafts as linkages in dynamic cumulus seeding effects. J. Appl. Meteor., 19, 477-487.

Smull, B. F., and J. A. Augustine, 1993: Multiscale analysis of a mature mesoscale convective complex. Mon. Wea. Rev., 121, $103-132$.

Stensrud, D. J., and J. M. Fritsch, 1994: Mesoscale convective systems in weakly forced large-scale environments. Part II: Generation of a mesoscale initial condition. Mon. Wea. Rev., 122, 2068-2083.

Stolzenburg, M., 1994: Observations of high ground flash densities of positive lightning in summertime thunderstorms. Mon. Wea. Rev., 122, 1740-1750.

Storm Data, 1986: Vol. 28, No. 2. [Available from National Climatic Data Center, Federal Building, Asheville, NC 28801.]

Tao, W. K., and J. Simpson, 1989: Modelling study of a tropical squall-type convective line. J. Atmos. Sci., 46, 177-202.

Velasco, I., and J. M. Fritsch, 1987: Mesoscale convective complexes in the Americas. J. Geophys. Res., 92 (D8), 9591-9613.

Wallace, J. M., 1975: Diurnal variations in precipitation and thunderstorm frequency over the conterminous United States. Mon. Wea. Rev., 103, 406-419.

Weekly Weather and Crop Bulletin, 1986: Vol. 73, No. 28. [Available from NOAA/NWS/NCEP, 4700 Silver Hill Rd., Stop 9910, Washington, DC 20233-9910.]

Weisman, M. L., J. B. Klemp, and R. Rotunno, 1988: Structure and evolution of numerically simulated squall lines. J. Atmos. Sci., 45, 1990-2013.

Westcott, N. E., 1994: Merging of convective clouds: Cloud initiation, bridging, and subsequent growth. Mon. Wea. Rev., 122, 780790.

Wilson, J. W., R. D. Roberts, C. Kessinger, and J. McCarthy, 1984: Microburst wind structure and evaluation of Doppler radar for airport wind shear detection. J. Climate Appl. Meteor., 23, 898915.

Wilson, K. J., and B. F. Ryan, 1986: The subsynoptic scale environment of mesoscale convective weather systems at genesis over southeastern Australia. Beitr. Phys. Atmos., 60, 210-228.

Yuter, S. E., and R. A. Houze Jr., 1995a: Three-dimensional kinematic and microphysical evolution of Florida cumulonimbus. Part I: Spatial distribution of updrafts, downdrafts, and precipitation. Mon. Wea. Rev., 123, 1921-1940.

_ , and _ 1995b: Three-dimensional kinematic and microphysical evolution of Florida cumulonimbus. Part II: Frequency distributions of vertical velocity, reflectivity, and differential reflectivity. Mon. Wea. Rev., 123, 1941-1963.

, and _ 1995c: Three-dimensional kinematic and microphysical evolution of Florida cumulonimbus. Part III: Vertical mass transport, mass divergence, and synthesis. Mon. Wea. Rev., 123, 1964-1983.

Zipser, E. J., 1982: Use of a conceptual model of the life cycle of mesoscale convective systems to improve very-short-range forecasts. Nowcasting, K. A. Browning, Ed., Academic Press, 191204.

_ R. J. Meitin, and M. A. Lemone, 1981: Mesoscale motion fields associated with a slowly-moving GATE convective band. $J$. Atmos. Sci., 38, 1725-1750. 